\title{
Article \\ Peptides Derived from Angiogenin Regulate Cellular Copper Uptake
}

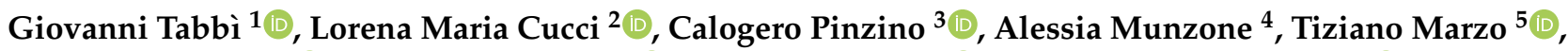

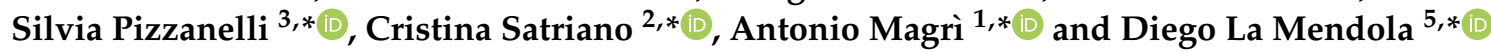

1 Institute of Crystallography—National Council of Research—CNR, via Paolo Gaifami 18, 95126 Catania, Italy; giovanni.tabbi@cnr.it

2 Nano Hybrid BioInterfaces Lab (NHBIL), Department of Chemical Sciences, University of Catania, Viale Andrea Doria 6, 95125 Catania, Italy; lorena.cucci@unict.it

3 Institute for the Chemistry of OrganoMetallic Compounds (ICCOM), National Council of Research-CNR, via G. Moruzzi 1, 56124 Pisa, Italy; calogero.pinzino@pi.iccom.cnr.it

4 Aix-Marseille Univesité, 52 Avenue Escadrille Normandie Niemen, 13013 Marseille, France; alessia.munzone@etu.univ-amu.fr

5 Department of Pharmacy, University of Pisa, via Bonanno Pisano 6, 56126 Pisa, Italy; tiziano.marzo@unipi.it

* Correspondence: silvia.pizzanelli@pi.iccom.cnr.it (S.P.); cristina.satriano@unict.it (C.S.); leotony@unict.it (A.M.); diego.lamendola@unipi.it (D.L.M.)

Citation: Tabbì, G.; Cucci, L.M.;

Pinzino, C.; Munzone, A.; Marzo, T.; Pizzanelli, S.; Satriano, C.; Magrì, A.; La Mendola, D. Peptides Derived from Angiogenin Regulate Cellular Copper Uptake. Int. J. Mol. Sci. 2021, 22, 9530. https://doi.org/10.3390/ ijms22179530

Academic Editor: Luigi Casella

Received: 18 May 2021

Accepted: 31 August 2021

Published: 2 September 2021

Publisher's Note: MDPI stays neutral with regard to jurisdictional claims in published maps and institutional affiliations.

Copyright: (c) 2021 by the authors. Licensee MDPI, Basel, Switzerland. This article is an open access article distributed under the terms and conditions of the Creative Commons Attribution (CC BY) license (https:/ / creativecommons.org/licenses/by/ $4.0 /)$.

\begin{abstract}
The angiogenin protein (ANG) is one of the most potent endogenous angiogenic factors. In this work we characterized by means of potentiometric, spectroscopic and voltammetric techniques, the copper complex species formed with peptide fragments derived from the N-terminal domain of the protein, encompassing the sequence 1-17 and having free amino, Ang1-17, or acetylated N-terminus group, AcAng1-17, so to explore the role of amino group in metal binding and cellular copper uptake. The obtained data show that amino group is the main copper anchoring site for Ang1-17. The affinity constant values, metal coordination geometry and complexes redox-potentials strongly depend, for both peptides, on the number of copper equivalents added. Confocal laser scanning microscope analysis on neuroblastoma cells showed that in the presence of one equivalent of copper ion, the free amino Ang1-17 increases cellular copper uptake while the acetylated AcAng1-17 strongly decreases the intracellular metal level. The activity of peptides was also compared to that of the protein normally present in the plasma (wtANG) as well as to the recombinant form (rANG) most commonly used in literature experiments. The two protein isoforms bind copper ions but with a different coordination environment. Confocal laser scanning microscope data showed that the wtANG induces a strong increase in intracellular copper compared to control while the rANG decreases the copper signal inside cells. These data demonstrate the relevance of copper complexes' geometry to modulate peptides' activity and show that wtANG, normally present in the plasma, can affect cellular copper uptake.
\end{abstract}

Keywords: electron spin resonance; copper; angiogenesis; peptide; ribonucleases; metal complexes; potentiometry; confocal microscopy

\section{Introduction}

Angiogenin (ANG) is the fifth member of the ribonuclease family (RNase) and, despite having weak catalytic activity $\left(\sim 10^{5}-10^{6}\right.$ lower than that of bovine pancreatic RNase), it is essential for angiogenesis stimulation [1,2]. The widespread expression and localization of angiogenin indicates that its physiological and pathological functions are not limited to the promotion of blood vessels growth.

In the last few years, it has been found that ANG acts as a neurotrophic and neuroprotective factor in neurodegenerative diseases such as Alzheimer's and Parkinson's diseases [3-8]. Furthermore, the ang gene is the first loss-of-function gene identified in 
patients affected by amyotrophic lateral sclerosis (ALS), suggesting a protective role of the protein towards motoneurons [9-12].

The precise mechanism by which ANG plays these multiple biological roles is not yet clear. Angiogenin must be internalized in the cells and translocated in the cell nucleus, to exploit its RNase catalytic activity, and explicate angiogenic activity [13,14].

ANG has three distinct functional domains: the RNase catalytic sites, consisting of residues His-13, Lys-40 and His-114; the putative cellular binding site encompassing the sequence 60-68 (KNGNPHREN), and the nuclear translocation site involving residues 31-35 (RRRGL) [2,15]. ANG was originally discovered as a tumor angiogenic factor, but it is present in human tissues, including the plasma and cerebrospinal fluid of healthy individuals [16-18]. In physiological conditions, ANG present in the plasma has no proliferative impact. It is therefore crucial to find out which factors may activate and modulate protein activity in different pathophysiological conditions.

Copper ions, which activate and amplify the angiogenic responses evoked by major pro-angiogenic stimuli, including the vascular endothelial growth factor (VEGF) and fibroblast growth factor (FGF) [19], could be among these factors. It is noteworthy that copper is the only mobilized metal going from intra- to extracellular space during the process of angiogenesis [20,21]. Moreover, serum copper levels increase in a wide variety of human cancers as well as in different neurodegenerative diseases [22-25]. Oxidative-induced inflammation is a common trait as additional cause of various neuronal pathologies [26] and copper is a redox active metal that can generate neurotoxic complexes leading to widespread oxidative stress condition in pathologies such as AD and ALS $[27,28]$. Beta amyloid $(\mathrm{A} \beta)$ can bind copper ions in the synaptic cleft, forming complex species with different coordination modes and redox potentials [29,30], leading to the formation of harmful reactive oxygen species (ROS) [31-33]. The triggering of oxidative stress can also induce the intracellular accumulation of copper, favoring lipid peroxidation, apoptosis and the formation of SOD1 aggregates [34]. It is worth noting that the amount the copper in some compartments may arise as in the synaptic cleft is high in relation to the neurotransmission of signals, where the basal level around $3 \mu \mathrm{M}$ can be rapidly enhanced to $100-250 \mu \mathrm{M}$ upon the excitatory pulse $[35,36]$ or during angiogenesis process, in which the copper is mobilized from inside to outside cells $[21,37]$. Therefore, it is reasonable to assume an interaction of copper ions with protein and peptides localized in the synaptic cleft or released during angiogenesis process as Angiogenin.

Moreover, it is evident that an altered copper homeostasis is observed in the pathologies in which abnormal levels of ANG are found and it is known that ANG plays a role in the inhibition of oxidative stress in ALS mouse models [38]. However, at present no evidence has been reported on a possible role of ANG in binding copper as a prevention of oxidative stress in neurodegenerative diseases. It is therefore relevant to consider whether ANG can affect intracellular copper levels and its localization, taking into account that in the cytosol copper is prevalently in the monovalent state.

In endothelial cells, copper can induce ANG expression, affect the intracellular protein distribution and the signaling pathways [39]. Additionally, the copper binding to ANG has been found to increase the protein interaction [40], to modulate protein interaction with actin [41], and to induce pro-angiogenic activity both in differentiated neuroblastoma (SH-SY5Y line) [42] and endothelial (HUVEC line) [43] cells.

The native protein (wtANG), which lacks the free amino terminal group, binds copper by involving His-13 and His-114 residues. On the other hand, the recombinant form (rANG), having an extra methionine as first residue, Met(-1), binds copper through its free $\mathrm{N}$-terminal amino group without the involving of C-terminal domain [44].

Biological active peptides can be designed or derived based on primary sequence from a native protein. In a previous work we synthesized two peptides, Ang1-17 and AcAng1-17, which encompass the sequence 1-17 of the Ang protein with the N-terminal amino group, respectively, free or acetylated, and demonstrated them having different coordination modes of copper ions due to the presence or absence of a free amino group. 
Accordingly, copper complexes of two peptides can differently affect actin microfilament organization in the cell cytoplasm [45].

In this work, we report the Electron Spin Resonance (ESR) and voltammetric characterization of copper complex species formed by Ang1-17 and AcAng1-17 peptides by exploiting both 1:1 and 2:1 metal-to-ligand (M/L) molar ratios, to elucidate on the copper coordination geometry and reduction potential of different species formed.

The potentiometric, UV-visible (UV-vis) and circular dichroism (CD) characterization has been previously reported only at M/L 1:1 [45]. Furthermore, confocal laser scanning microscopy (LSM) measurements were carried out on SH-SY5Y cells stained with copper sensor1 (CS1) [46], a fluorescent probe of $\mathrm{Cu}^{+}$, to investigate the potential ability of angiogenin derived peptide fragments to modulate the level of intracellular copper ions.

The activity of the peptides was assessed at different metal-to-ligand molar ratios and compared with those of wtANG and rANG.

\section{Results}

The coordination ability, as well as the distribution of the species as function of the $\mathrm{pH}$ values for Ang1-17 and its acetylated form AcAng1-17 with $\mathrm{Cu}$ (II) ion at 1:1 metal-to-ligand molar ratio, have been thoroughly investigated in a previous work [45] and the distribution diagrams are reported here for clarity (Figure 1).

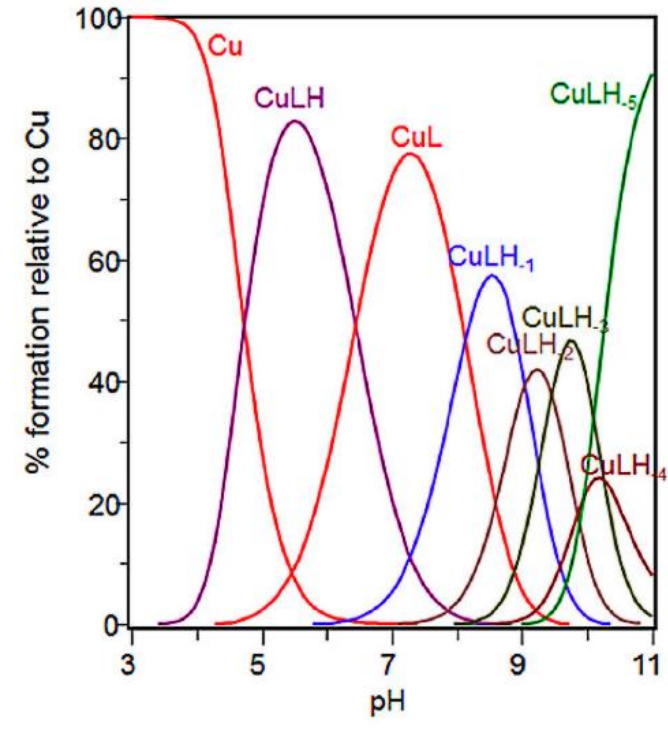

(a)

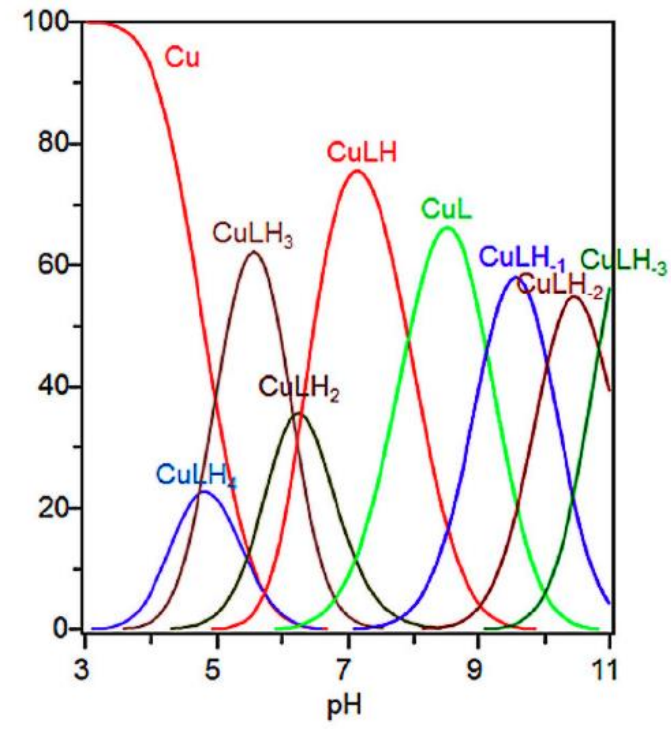

(b)

Figure 1. Species distribution of copper(II) complexes with: (a) Ang1-17; and (b) AcAng1-17. $[\mathrm{L}]=1 \times 10^{-3} \mathrm{M}$; metal-to-ligand molar ratio of 1:1. From Ref. [45], under Attribution 4.0 International, CC BY 4.0.

\subsection{ESR Study on Cu(II)-Ang1-17 System (M/L 1:1)}

The main species formed by the $\mathrm{Cu}(\mathrm{II})-\mathrm{Ang} 1-17$ system are $[\mathrm{CuLH}]$ and $[\mathrm{CuL}]$ in the $\mathrm{pH}$ range 5-8.

The ESR spectra were run at different $\mathrm{pH}$ values to obtain more details about the copper coordination geometry in the different complex species. The Hamiltonian parameters of the $[\mathrm{CuLH}]$ isomer species were obtained by simulation of the spectrum run at $\mathrm{pH}=3.9$ previously subtracted from the $\mathrm{Cu}$ (II) hexaaquo ion features (Figure 2a). The Hamiltonian parameters of $[\mathrm{CuLH}]$ isomers are $\mathrm{g}_{||}=2.335, \mathrm{~A}_{||}=146 \times 10^{-4} \mathrm{~cm}^{-1}$ and $\mathrm{g}_{||}=2.295$, $A_{\mid ।}=176 \times 10^{-4} \mathrm{~cm}^{-1}$, which contribute roughly equally. In addition, a small amount of a complex having $\mathrm{g}_{||}=2.250, \mathrm{~A}_{||}=185 \times 10^{-4} \mathrm{~cm}^{-1}$ was found to also be present at higher a $\mathrm{pH}$. 
$M: L$ 0.9:1

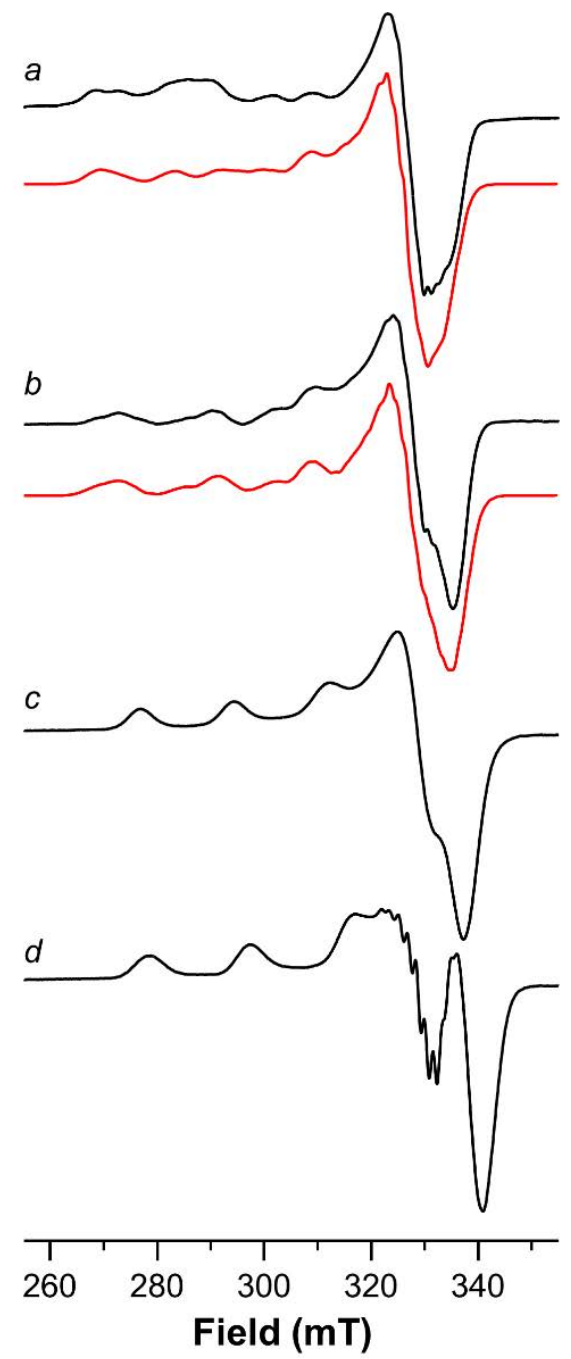

$M: L$ 1.8:1
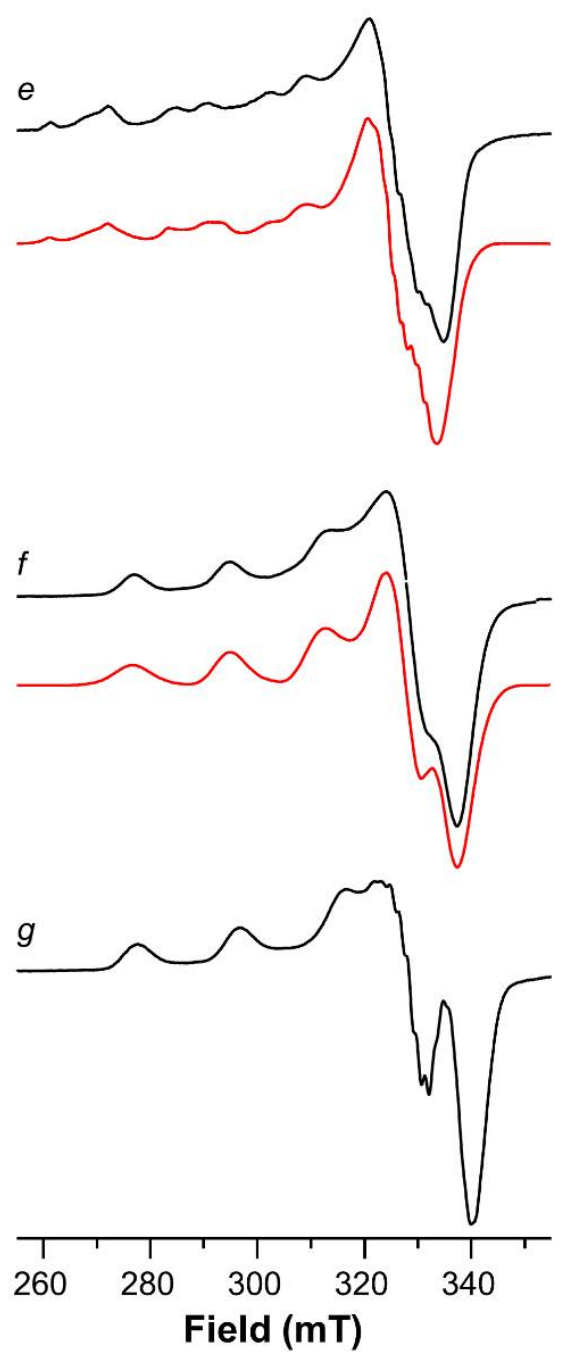

Figure 2. ESR spectra at $150 \mathrm{~K}$ of ${ }^{63} \mathrm{Cu}(\mathrm{II})-\mathrm{Ang} 1-17$ system (a-d, M:L 0.9:1) and ${ }^{63} \mathrm{Cu}(\mathrm{II})$-Ang1-17 system (e.g., M:L 1.8:1) in aqueous solution as a function of the $\mathrm{pH}$ : (a) 3.9 subtracted from the $\left[{ }^{63} \mathrm{Cu}\left(\mathrm{H}_{2} \mathrm{O}\right)_{6}\right]^{2+}$ features; (b) 4.5 ; (c) 7.3 ; (d) 10.5 ; (e) 5.5 (subtracted from the spectrum at $\mathrm{pH}=6.0$ ); (f) $7.4 ;($ g) 10.0. Simulated spectra are shown by the red line.

Raising the $\mathrm{pH}$ value to 4.5 (Figure $2 \mathrm{~b}$ ), the $[\mathrm{CuLH}]$ isomer $\left(\mathrm{g}_{\mid} \mid=2.295\right.$, $\mathrm{A}_{||}=176 \times 10^{-4} \mathrm{~cm}^{-1}$ ) continued to persist, but the main species is characterized by $\mathrm{g}_{||}=2.250$ and $\mathrm{A}_{||}=185 \times 10^{-4} \mathrm{~cm}^{-1}$.

In the 5.3-8.2 pH range, only one species was detected in the ESR spectra (Figure 2c), and the Hamiltonian parameters are characterized by $\mathrm{g}_{||}=2.224, \mathrm{~A}_{||}=186 \times 10^{-4} \mathrm{~cm}^{-1}$, drawn directly from the spectrum.

At $\mathrm{pH}=9.2$ and above, single species spectra (Figure 2d) were recorded, for which the Hamiltonian parameters are invariably $\mathrm{g}_{||}=2.194, \mathrm{~A}_{||}=201 \times 10^{-4} \mathrm{~cm}^{-1}$, although a more resolved superfine structure in the perpendicular part of the spectrum is visible at $\mathrm{pH}=10.5$.

Further deprotonation steps occurring at higher $\mathrm{pH}$ values concern the Tyr and Lys residues, which are not directly involved in the $\mathrm{Cu}$ (II) coordination. 


\subsection{Potentiometric and ESR Studies on Cu(II)-Ang1-17 System (M/L 2:1)}

Potentiometric measurements were carried out by using 2:1 metal-to-ligand molar ratio. As a matter of fact, with the addition of two copper(II) equivalents, only complex species in which the peptide binds two metal ions are observed.

The stability constant values obtained are reported in Table 1 and the corresponding distribution diagram is shown in Figure 3a.

Table 1. $\log \beta$ and $\log \mathrm{K}$ values obtained from the titration of the $\mathrm{Cu}-\mathrm{Ang} 1-17$ system (2:1), by varying the solution $\mathrm{pH}$ in the range 3-9.5.

\begin{tabular}{|c|c|c|c|c|}
\hline $\begin{array}{c}\text { Species } \\
{\left[\mathrm{Cu}_{\mathrm{p}} \mathrm{L}_{\mathrm{q}} \mathrm{H}_{\mathrm{r}}\right]}\end{array}$ & $\log \beta *$ & $\log K$ & $\begin{array}{r}\operatorname{UV}\left(\lambda_{\text {max }}, \varepsilon_{\text {max }}\right) \\
\left(\mathrm{nm}, \mathbf{M}^{-1} \mathbf{c m}^{-1}\right)\end{array}$ & $\begin{array}{c}\operatorname{CD}(\lambda, \Delta \varepsilon) \\
\left(\mathrm{nm}, \mathrm{M}^{-1} \mathrm{~cm}^{-1}\right)\end{array}$ \\
\hline 211 & $17.28(1)$ & - & - & - \\
\hline 210 & $12.67(2)$ & 4.60 & $650(110)$ & $266(+0.25), 299(-1.15), 602(+0.25)$ \\
\hline $21-1$ & $7.02(2)$ & 5.65 & - & - \\
\hline $21-3$ & $-4.74(2)$ & $5.88 \times 2$ & $602(227)$ & $\begin{array}{c}260(+7.43), 303(-1.45), 342(+0.45), 532 \\
(+0.33), 625(-0.33)\end{array}$ \\
\hline $21-4$ & $-11.21(3)$ & 6.47 & - & - \\
\hline $21-5$ & $-18.13(3)$ & 6.92 & See text & $\begin{array}{c}261(+8.90), 301(-0.73), 321(+0.35), 350 \\
(-0.35), 491(-1.00), 669(+0.78)\end{array}$ \\
\hline $21-6$ & $-26.33(3)$ & 8.19 & - & - \\
\hline $21-7$ & $-34.99(3)$ & 8.66 & $532(380)$ & $\begin{array}{c}270(+3.31), 302(+0.97), 343(-0.98), 514 \\
(-0.93), 661(+1.06)\end{array}$ \\
\hline
\end{tabular}

$* 3 \sigma$ in parentheses.

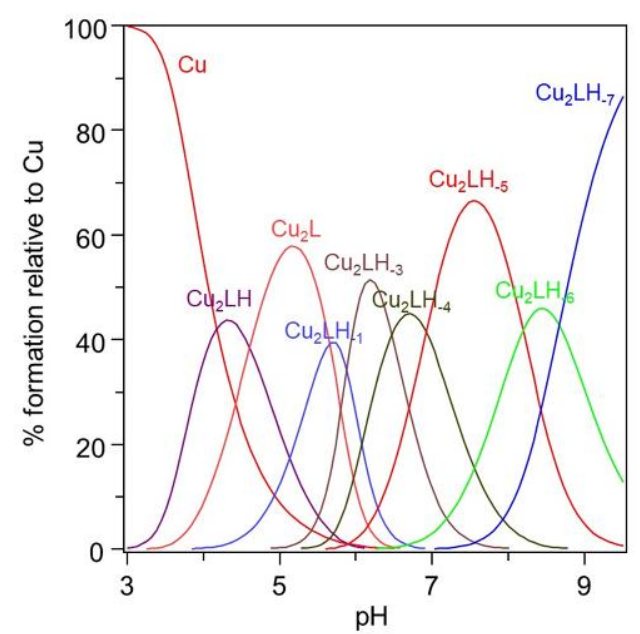

(a)

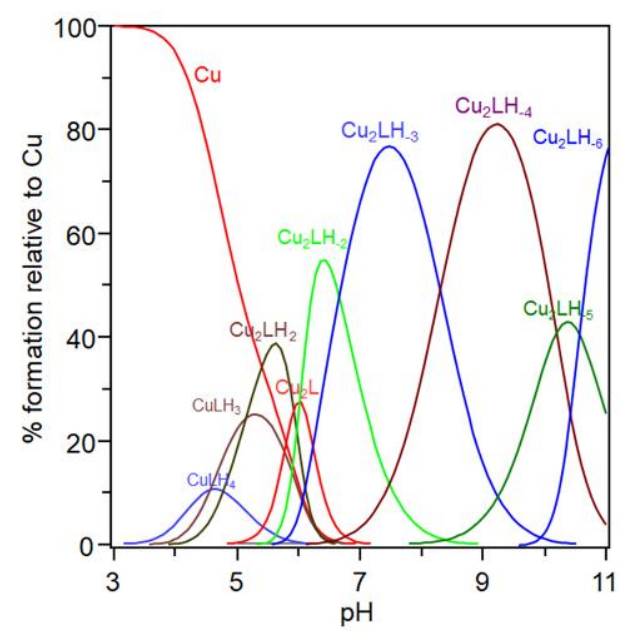

(b)

Figure 3. Species distribution of copper(II) complexes with: (a) Ang1-17; and (b) AcAng1-17. $[\mathrm{L}]=1 \times 10^{-3} \mathrm{M}$; metal-to-ligand molar ratio of 2:1.

The Ang1-17 peptide has five protonation constants $\left(\left[\mathrm{LH}_{5}\right]\right.$, i.e., two carboxylic side chains, two imidazole rings and the terminal amino moiety), whereas the stability constant values of deprotonation of the Tyr and Lys side chains for this ligand were not determined due to precipitation phenomena, as previously reported [45].

Starting from $\mathrm{pH}=3$, the $\left[\mathrm{Cu}_{2} \mathrm{LH}\right]$ complex species is formed. The number of released protons and the stability constant value suggest that each copper ion may be bound to one imidazole and one carboxylate group. It is also possible that an isomer in which $\mathrm{N}$-terminal amino group is bound to copper with one imidazole still protonated. However, spectroscopic data cannot be determined for $\left[\mathrm{Cu}_{2} \mathrm{LH}\right]$ species due to the presence of free copper ions and other metal complexes species. Therefore, it is not possible to make specific assertions about the main metal anchoring sites at low $\mathrm{pH}$ values. 
Increasing the $\mathrm{pH}$, the $\left[\mathrm{Cu}_{2} \mathrm{~L}\right]$ complex species is formed. Potentiometric data (log $\left.\mathrm{K}_{210}=\log \beta_{211}-\log \beta_{210}=4.60\right)$ indicate the simultaneous involvement of two imidazole nitrogen atoms in copper binding to determine $\mathrm{a}\left(2 \mathrm{~N}_{\mathrm{Im}}, \mathrm{O}_{\mathrm{COO}-}\right)$ coordination environment for one metal ion whereas the second $\mathrm{Cu}$ (II) ion may be bound through $\mathrm{NH}_{2}$ terminal group $\left(\mathrm{NH}_{2}, \mathrm{O}_{\mathrm{COO}-}\right)$ [47]. The UV-vis spectroscopic parameters confirm this coordination mode (see Table 1, Figure S1).

Increasing the $\mathrm{pH}$, the $\left[\mathrm{Cu}_{2} \mathrm{LH}_{-1}\right]$ is formed. Due to the superimposition of the other complex species, the UV-vis parameters could not be determined for this complex species. In the $\mathrm{CD}$ spectrum recorded at $\mathrm{pH}=5.8$ (Figure S2), a $\mathrm{N}^{-} \rightarrow \mathrm{Cu}$ (II) CT band centered at $338 \mathrm{~nm}$ (overlapped with the $\mathrm{N}_{\mathrm{Im}} \rightarrow \mathrm{Cu}$ (II) CT band) is present that, combined with the $\log \mathrm{K}$ value determined by potentiometric titrations, is a concrete clue to the involvement of a deprotonated nitrogen atom in this complex species $\left(\log K_{21-1}=\log \beta_{210}-\log \beta_{21-1}=5.65\right)[48,49]$.

The ESR spectrum run on $\mathrm{Cu}$ (II)-Ang1-17 at $\mathrm{pH}=5.5$, shows the patterns of at least two coordination modes, beside the signal due to due the copper(II) hexaaquo ion. Comparing spectra at different $\mathrm{pH}$ values, it is clear that the spectrum run at $\mathrm{pH}=5.5$ also contains a contribution deriving from the features of the species found at a $\mathrm{pH}$ value of 6.0 (which is, in turn, very similar to that found at $\mathrm{pH}=7.4$ ). To ease the computation, the spectral contribution of the ESR spectrum at $\mathrm{pH}=6.0$ was subtracted from that taken at $\mathrm{pH}=5.5$ and the resulting spectrum was simulated (Figure 2e). A satisfactory simulation was achieved by using the following Hamiltonian parameters: $\mathrm{g}_{||}=2.245, \mathrm{~A}_{||}=186 \times 10^{-4} \mathrm{~cm}^{-1}$ and $\mathrm{g}_{||}=2.295, \mathrm{~A}_{||}=176 \times 10^{-4} \mathrm{~cm}^{-1}$, in agreement with the environments identified by potentiometric and UV-vis data.

On raising the $\mathrm{pH}$ value, a cooperative deprotonation of two nitrogen atoms occurred, hence the $\left[\mathrm{Cu}_{2} \mathrm{LH}_{-3}\right]$ species was formed and reached its maximum percentage of formation at $\mathrm{pH}=6.4$. The two $\mathrm{Cu}(\mathrm{II})$ ions have very similar coordination environments, as evidenced by the symmetric and quite sharp UV-vis band centered at $602 \mathrm{~nm}$. Two $3 \mathrm{~N} 1 \mathrm{O}$ coordination modes can be hypothesized for the two $\mathrm{Cu}(\mathrm{II})$ binding site: in the first environment $\mathrm{NH}_{2}, \mathrm{~N}^{-}, \mathrm{N}_{\mathrm{Im}}, \mathrm{O}_{\mathrm{COO}-}$ is present at the peptide $\mathrm{N}$-terminus, whereas a $\mathrm{N}_{\mathrm{Im}}, 2 \mathrm{~N}^{-}$coordination mode involves the second $\mathrm{Cu}(\mathrm{II})$ ion. The deprotonation of the two coordinating nitrogen atoms is confirmed by their averaged $\log \mathrm{K}$ value $(5.88 \times 2)$ as well as by the intensity increase in the $\mathrm{N}^{-} \rightarrow \mathrm{Cu}$ (II) CT band at $338 \mathrm{~nm}$ observed in the $\mathrm{CD}$ spectrum recorded at $\mathrm{pH}=6.3$.

Regarding the $\left[\mathrm{Cu}_{2} \mathrm{LH}_{-4}\right]$ species, another peptide nitrogen atom deprotonation occurred, as evidenced by its $\log \mathrm{K}$ value. Unfortunately, an unequivocal assignment of the residue involved in the nitrogen deprotonation was not possible due to the similarity of the two $\mathrm{Cu}(\mathrm{II})$ coordination sites.

The main complex species present at physiological $\mathrm{pH}$ is the $\left[\mathrm{Cu}_{2} \mathrm{LH}_{-5}\right]$ species, in which both copper(II) ions are coordinated to the peptide by four nitrogen atoms. The first coordination mode involves $\mathrm{NH}_{2}, 2 \mathrm{~N}^{-}, \mathrm{N}_{\text {Im }}$ donor atoms, whereas the second $\mathrm{Cu}$ (II) ion is bound to the peptide by an imidazole nitrogen atom and three deprotonated amide nitrogen atoms, i.e., $\mathrm{N}_{\mathrm{im}}, 3 \mathrm{~N}^{-}$. A very broad $\mathrm{UV}$-vis band was recorded for this complex, resulting from two partially superimposed gaussian peaks centered at $\lambda_{\max }$ of $585 \mathrm{~nm}$ and $535 \mathrm{~nm}$ and characterized by a comparable intensity, due to the two $\mathrm{CuN}_{4}$ chromophores (i.e., $\mathrm{NH}_{2}, 2 \mathrm{~N}^{-}, \mathrm{N}_{\mathrm{Im}}$ and $\mathrm{N}_{\mathrm{im}}, 3 \mathrm{~N}^{-}$, respectively).

In the $\mathrm{pH}$ range 6-8 only an ESR pattern was recorded. The averaged parameters drawn directly from these ESR spectra are $\mathrm{g}_{||}=2.218, \mathrm{~A}_{||}=191 \times 10^{-4} \mathrm{~cm}^{-1}$ (Figure 2f). These spectra were satisfactorily simulated by using two sets of Hamiltonian parameters, i.e., $\mathrm{g}_{||}=2.228, \mathrm{~A}_{||}=184 \times 10^{-4} \mathrm{~cm}^{-1}$ and $\mathrm{g}_{||}=2.208, \mathrm{~A}_{||}=187 \times 10^{-4} \mathrm{~cm}^{-1}$. Additionally, the ESR spectrum run at $\mathrm{pH}=8.5$ (not shown) shows a broadening on the parallel features due to the presence of similar coordination environments, and their averaged Hamiltonian parameters are $\mathrm{g}_{||}=2.209, \mathrm{~A}_{||}=194 \times 10^{-4} \mathrm{~cm}^{-1}$.

Finally, upon increasing the $\mathrm{pH}$ above the physiological value, another two complex species were formed, i.e., $\left[\mathrm{Cu}_{2} \mathrm{LH}_{-6}\right]$ and $\left[\mathrm{Cu}_{2} \mathrm{LH}_{-7}\right]$. A $4 \mathrm{~N}$ coordination mode $\left(\mathrm{N}_{\mathrm{Im}}, 3 \mathrm{~N}^{-}\right.$ and $\mathrm{NH}_{2}, 3 \mathrm{~N}^{-}$, respectively) for the two copper(II) centers occurs, as demonstrated by 
the presence of a UV-vis band centered at $532 \mathrm{~nm}$. Further support for this hypothesis comes from the presence in the CD spectrum of the CT bands at $270 \mathrm{~nm}\left(\mathrm{~N}_{\mathrm{im}} \pi_{2} \rightarrow\right.$ $\left.\mathrm{Cu}^{2+}\right)$, at $301 \mathrm{~nm}\left(\mathrm{NH}_{2} \rightarrow \mathrm{Cu}^{2+}\right)$ and at $343 \mathrm{~nm}\left(\mathrm{~N}_{\mathrm{im}} \rightarrow \mathrm{Cu}^{2+}\right.$ overlapped with $\mathrm{N}^{-} \rightarrow$ $\left.\mathrm{Cu}^{2+}\right)$. Only above $\mathrm{pH}=8.5$ sharp parallel features appeared in the ESR spectra with parameters approximately keeping the same values shown at physiological $\mathrm{pH}$ (Figure $2 \mathrm{~g}$ ), i.e., $\mathrm{g}_{||}=2.196, \mathrm{~A}_{||}=205 \times 10^{-4} \mathrm{~cm}^{-1}$.

\subsection{ESR Study on Cu(II)-AcAng1-17 System (M/L 1:1)}

The ESR spectrum of $\mathrm{Cu}(\mathrm{II})$-AcAng1-17 with equimolar amounts of metal and ligand at a $\mathrm{pH}$ of around 4 reveals the features of two complex species as well as those belonging to copper(II) hexaaquo ion (data not shown). The Hamiltonian parameters of the two complex species are $\mathrm{g}_{||}=2.332, \mathrm{~A}_{||}=158 \times 10^{-4} \mathrm{~cm}^{-1}$ and $\mathrm{g}_{||}=2.295, \mathrm{~A}_{||}=176 \times 10^{-4} \mathrm{~cm}^{-1}$, attributable to $\left[\mathrm{CuLH}_{4}\right]$ and $\left[\mathrm{CuLH}_{3}\right]$ species, are compatible with $\mathrm{N}_{\mathrm{Im}}, \mathrm{O}_{\mathrm{COO}-}$ and $2 \mathrm{~N}_{\mathrm{Im}}$, $\mathrm{O}_{\mathrm{COO}-}$ coordination modes, respectively.

Only a species having the latter set of parameters is observed at $\mathrm{pH}=5$ (Figure 4a), i.e., the $\left[\mathrm{CuLH}_{3}\right]$ species.

$M: L \quad 0.9: 1$
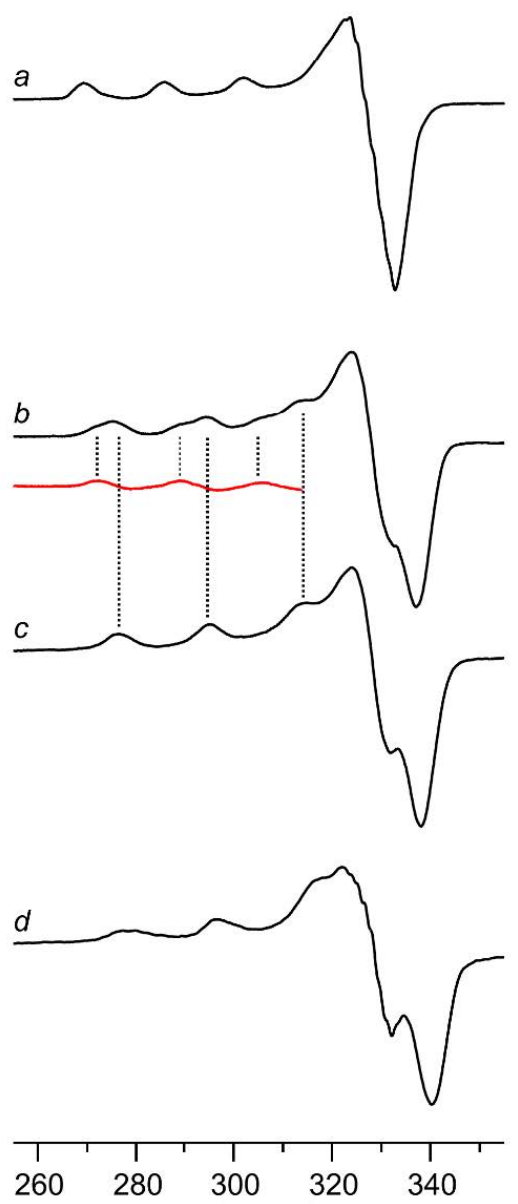

Field (mT)
$M: L 1.8: 1$

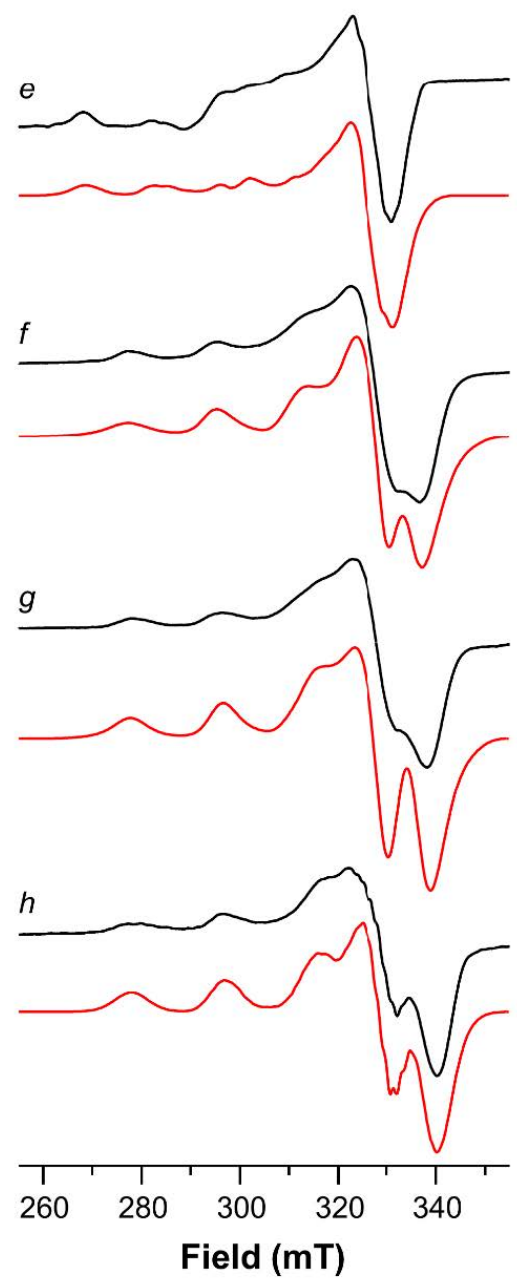

Figure 4. ESR spectra at $150 \mathrm{~K}$ of ${ }^{63} \mathrm{Cu}(\mathrm{II})$-AcAng1-17 system (a-d, M:L 0.9:1) and ${ }^{63} \mathrm{Cu}(\mathrm{II})$-AcAng117 system (e-h, M:L 1.8:1) in aqueous solution as function of the $\mathrm{pH}$ : (a) 5.0; (b) 6.0 (the red trace represents the parallel features of the spectrum of trace at $\mathrm{pH} 6.0$ minus trace at $\mathrm{pH} 6.9) ;(\mathrm{c}) 6.9$; (d) 10.8; (e) 4.3 (subtracted from $\left[{ }^{63} \mathrm{Cu}\left(\mathrm{H}_{2} \mathrm{O}\right)_{6}\right]^{2+}$ features); (f) 6.4; (g) 7.6; (h) 10.8. Simulated spectra on the right panel are shown by the red line. 
At $\mathrm{pH}=6$ the patterns belonging to two different species are clearly visible in the ESR spectrum (Figure $4 \mathrm{~b}$ ) characterized by $\mathrm{g}_{||}=2.266, \mathrm{~A}_{||}=180 \times 10^{-4} \mathrm{~cm}^{-1}$ and $\mathrm{g}_{||}=2.212$ and $A_{||}=196 \times 10^{-4} \mathrm{~cm}^{-1}$. The former set is assigned to $\left[\mathrm{CuLH}_{2}\right]$ species, whereas the latter to the $[\mathrm{CuLH}]$ species (Figure $4 \mathrm{c}$ ), the ESR spectrum of which begins to be present at $\mathrm{pH}=6$ and is the only detectable until $\mathrm{pH}=8$. The hypothesized coordination modes for $\left[\mathrm{CuLH}_{2}\right]$ and $[\mathrm{CuLH}]$ species are $2 \mathrm{~N}_{\mathrm{Im}}, \mathrm{N}^{-}$, and $2 \mathrm{~N}_{\mathrm{Im}}, 2 \mathrm{~N}^{-}$, respectively.

On raising the $\mathrm{pH}$ value, last amide nitrogen is deprotonated and coordinates the $\mathrm{Cu}$ (II) ion, the ESR spectra being characterized by $\mathrm{g}_{||}=2.199$ and $\mathrm{A}_{||}=205 \times 10^{-4} \mathrm{~cm}^{-1}$ (Figure $4 \mathrm{~d}$ ). These parameters are compatible with a $\mathrm{N}_{\mathrm{Im}}, 3 \mathrm{~N}^{-}$coordination mode.

\subsection{Potentiometric and ESR Studies on Cu(II)-AcAng1-17 System (M/L 2:1)}

Despite the lack of the amino group, the peptide AcAng1-17 still possesses two anchoring sites for $\mathrm{Cu}$ (II) ion, i.e., the two His residues. With the aim of testing the ability to form dicopper(II) species, two equivalents of the $\mathrm{Cu}$ (II) ion were added to a solution of the AcAng1-17 peptide.

The AcAng1-17 peptide is also able to form up to a 2:1 metal-to-ligand ratio complex species with $\mathrm{Cu}$ (II) ions. The stability constant values obtained are reported in Table 2 and the corresponding distribution diagrams in Figure 3b, respectively.

Table 2. $\log \beta$ and $\log \mathrm{K}$ values obtained from the titration of the $\mathrm{Cu}-\mathrm{AcAnn} 1-17$ system (2:1), by varying the solution $\mathrm{pH}$ in the range $3-11$.

\begin{tabular}{|c|c|c|c|c|}
\hline $\begin{array}{c}\text { Species } \\
{\left[\mathrm{Cu}_{\mathrm{p}} \mathrm{L}_{\mathrm{q}} \mathrm{H}_{\mathrm{r}}\right]}\end{array}$ & $\log \beta *$ & $\log \mathrm{K}$ & $\begin{array}{r}\mathrm{UV}\left(\lambda_{\max }, \varepsilon_{\max }\right) \\
\left(\mathrm{nm}, \mathbf{M}^{-1} \mathrm{~cm}^{-1}\right)\end{array}$ & $\begin{array}{c}\mathrm{CD}(\lambda, \Delta \varepsilon) \\
\left(\mathrm{nm}, \mathbf{M}^{-1} \mathrm{~cm}^{-1}\right)\end{array}$ \\
\hline 114 & $40.38(1)$ & - & $-* *$ & $-* *$ \\
\hline 113 & $35.82(1)$ & 4.56 & $650(60)^{* *}$ & $258(2.52) ; 331(0.30) ; 598(-0.24)^{* *}$ \\
\hline 212 & $33.50(2)$ & - & See text & $334(+0.04) ; 528(+0.03)$ \\
\hline $21-0$ & $21.95(2)$ & $(5.77 \times 2)$ & - & - \\
\hline $21-2$ & $9.56(3)$ & $(6.19 \times 2)$ & See text & $\begin{array}{c}260(+6.69) ; 326(+0.47) ; 486(-0.33) ; 546 \\
(+0.28) ; 609(-0.19) ; 681(+0.30)\end{array}$ \\
\hline $21-3$ & $2.94(3)$ & 6.62 & $532(250)$ & $\begin{array}{c}262(+7.30) ; 320(+0.70), 360(-0.27), 495 \\
(-1.08), 560(+0.32), 665(+0.90)\end{array}$ \\
\hline $21-4$ & $-5.36(6)$ & 8.30 & $528(242)$ & $\begin{array}{c}264(+7.95) ; 347(-1.08) ; 492(-1.12) ; 650 \\
(+1.35)\end{array}$ \\
\hline $21-5$ & $-15.55(8)$ & 10.19 & - & - \\
\hline $21-6$ & $-26.10(5)$ & 10.65 & $528(230)$ & $\begin{array}{c}265(+8.05) ; 347(-0.66) ; 501(-2.06) ; 646 \\
(+1.30)\end{array}$ \\
\hline
\end{tabular}

*3 $\sigma$ in parentheses; ${ }^{* *}$ Reference [45].

Differently from the case of the non-acetylated Ang1-17 peptide, all protonation stability constants of AcAng1-17 peptide were determined (two carboxylic side chains, two imidazole rings and one Tyr and two Lys side chains), as previously reported [45]. At acidic $\mathrm{pH}$ values, two complex species, $\left(\left[\mathrm{CuLH}_{4}\right]\right.$ and $\left.\left[\mathrm{CuLH}_{3}\right]\right)$, each binding only one $\mathrm{Cu}(\mathrm{II})$ ion, were found.

In the 4.3-5.6 $\mathrm{pH}$ range, the ESR spectra revealed, besides some residual $\mathrm{Cu}(\mathrm{II})$ hexaaquo ion, the presence of two distinct patterns of signals. The parameters obtained by simulation of the spectrum (Figure 4e, red trace) are $\mathrm{g}_{||}=2.290, \mathrm{~A}_{||}=170 \times 10^{-4} \mathrm{~cm}^{-1}$ and $\mathrm{g}_{||}=2.332, \mathrm{~A}_{||}=158 \times 10^{-4} \mathrm{~cm}^{-1}$ and can be assigned to $\left[\mathrm{CuLH}_{3}\right]$ and $\left[\mathrm{CuLH}_{4}\right]$, respectively, with copper coordination modes $\mathrm{N}_{\mathrm{Im}}, \mathrm{N}^{-}, \mathrm{O}_{\mathrm{COO}-}$ and $\mathrm{N}_{\mathrm{Im}}, \mathrm{O}_{\mathrm{COO}-}$.

Around $\mathrm{pH}$ values of 5.5, $\left[\mathrm{Cu}_{2} \mathrm{LH}_{2}\right]$ complex species is formed. The deconvoluted UV-vis spectrum for this complex species showed a very broad band resulting from the overlap of two distinct bands (Figure S3). The determined $\lambda_{\max }$ values (705 $\mathrm{nm}$ and $635 \mathrm{~nm}$ ) are indicative of two $\mathrm{Cu}(\mathrm{II})$ ions bound to the peptide via two different coordination modes. The UV-vis band centered at $705 \mathrm{~nm}$ is typical of a $1 \mathrm{~N} 1 \mathrm{O} \mathrm{N}_{\mathrm{Im}}, \mathrm{O}_{\mathrm{COO}-}$ coordination mode, whereas the band centered at $635 \mathrm{~nm}$ corresponds to a $2 \mathrm{~N} 1 \mathrm{O} \mathrm{N} \mathrm{N}_{\mathrm{Im}}, \mathrm{N}^{-}, \mathrm{O}_{\mathrm{COO}}$ environment, as found in previous works [50,51]. In the deconvoluted CD spectrum, a 
band with a maximum centered at $334 \mathrm{~nm}$ is found, which is an overlap between the CT bands related to the $\mathrm{N}_{\mathrm{im}} \rightarrow \mathrm{Cu}$ (II) and the $\mathrm{N}^{-}$(amide) $\rightarrow \mathrm{Cu}$ (II) CT transitions, respectively (Figure S4).

Then, the occurrence of a cooperative deprotonation with the consequent formation of the $\left[\mathrm{Cu}_{2} \mathrm{~L}\right]$ complex species was found only by potentiometric technique. Its averaged $\log \mathrm{K}$ value is very similar to a typical value found for the deprotonation of two amide atoms [52]. Unfortunately, a spectroscopic characterization was not feasible.

Increasing the $\mathrm{pH}$, another cooperative deprotonation of two nitrogen atoms occurred with the formation of the $\left[\mathrm{Cu}_{2} \mathrm{LH}_{-2}\right]$ complex species, as determined by potentiometric data, which are in a good agreement with those found in the literature. The deconvoluted UV-vis spectrum for this complex species $\left(\lambda_{\max }=565 \mathrm{~nm}\right)$ is a linear combination of two single bands. The first band is centered at $535 \mathrm{~nm}$, which is in a good agreement with a $4 \mathrm{~N}$ $\left(\mathrm{N}_{\mathrm{Im}}, 3 \mathrm{~N}^{-}\right)$coordination mode for a $\mathrm{Cu}(\mathrm{II})$ ion [53]. Instead, the second band is centered at $590 \mathrm{~nm}$, hence supporting the presence of a $3 \mathrm{~N}\left(\mathrm{~N}_{\mathrm{Im}}, 2 \mathrm{~N}^{-}\right)$coordination mode for the other metal ion [50].

In the $\mathrm{CD}$ spectrum a band with a maximum centered at $326 \mathrm{~nm}$ was found. Such a broad band is a combination of the $\mathrm{CT}$ bands relative to a $\mathrm{N}_{\mathrm{Im}} \rightarrow \mathrm{Cu}$ (II) transition and to a $\mathrm{N}^{-} \rightarrow \mathrm{Cu}$ (II) transition. In addition, the band centered at $260 \mathrm{~nm}$ corresponds to a $\mathrm{N}_{\mathrm{Im}} \pi_{2}$ $\rightarrow \mathrm{Cu}$ (II) charge transfer transitions. Finally, the bands centered at $486 \mathrm{~nm}, 546 \mathrm{~nm}, 609 \mathrm{~nm}$ and $681 \mathrm{~nm}$ refer to the $\mathrm{d}-\mathrm{d}$ transitions of both coordination sites [54].

The ESR spectrum run at $\mathrm{pH}$ value of 6.4 was quite broad (Figure $4 \mathrm{f}$ ); a simulation was performed considering two species and the following parameters were found $\mathrm{g}_{||}=2.220$, $\mathrm{A}_{||}=184 \times 10^{-4} \mathrm{~cm}^{-1}$ and $\mathrm{g}_{||}=2.200, \mathrm{~A}_{||}=190 \times 10^{-4} \mathrm{~cm}^{-1}$. These parameters agree with the coordination modes hypothesized for $\mathrm{Cu}_{2} \mathrm{LH}_{-2}$ species using UV-vis spectroscopy and $\mathrm{CD}$ measurements.

At physiological $\mathrm{pH}$, the main complex species is $\left[\mathrm{Cu}_{2} \mathrm{LH}_{-3}\right]$. The calculated $\log \mathrm{K}$ for this step is indicative of another deprotonation of nitrogen atom, which led to the formation of two equivalent complexation sites in which every single $\mathrm{Cu}$ (II) ion is coordinated to the peptide by a $4 \mathrm{~N}\left(\mathrm{~N}_{\mathrm{Im}}, 3 \mathrm{~N}^{-}\right)$donor set. This coordination mode is confirmed by the $\mathrm{g}_{||}$and

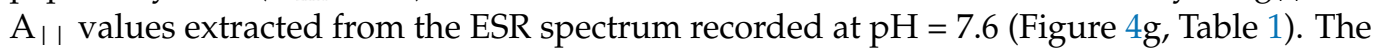
UV-vis band for this complex species is narrow, very symmetric and its $\lambda_{\max }$ is centered at $532 \mathrm{~nm}$. This value is in a good agreement with those found for similar peptide systems having the same coordination environment [53].

In the CD spectrum calculated for this complex species, the same CT and d-d bands observed for the previous species were found, but in this case the $\mathrm{N}^{-} \rightarrow \mathrm{Cu}$ (II) and the $\mathrm{N}_{\mathrm{Im}} \rightarrow \mathrm{Cu}$ (II) $\mathrm{CT}$ transitions are distinct, with the first being centered at $320 \mathrm{~nm}$ and the second at $360 \mathrm{~nm}$. These values are compatible with the coordination environment proposed above [47].

Upon increasing the $\mathrm{pH}$ above 7 , another three deprotonation steps were found without significant variations in UV-vis, CD and ESR spectra. (Figure 4h, Tables 2 and 3). Potentiometric data indicate that these deprotonation steps come from the $\mathrm{OH}$ and $\mathrm{NH}_{2}$ moieties of one Tyr and two Lys side chain residues, respectively [50]. 
Table 3. ESR parallel Hamiltonian parameters and formal redox potentials of copper(II) with Ang1-17 and AcAng1-17 at different metal-to-ligand ratios.

\begin{tabular}{|c|c|c|c|c|}
\hline \multicolumn{5}{|c|}{$C u(I I)-A n g 1-17$ 1:1 } \\
\hline $\mathrm{pH}$ & $g_{\mid I}$ & $A_{11}$ & Donor Set & $\mathrm{E}_{\mathrm{f}}^{\circ}(\mathrm{SWV})$ \\
\hline \multirow[t]{4}{*}{3.9} & 2.424 & 124 & $6 \mathrm{H}_{2} \mathrm{O}$ & \\
\hline & 2.250 & 185 & $\mathrm{NH}_{2}, \mathrm{~N}^{-}, \mathrm{O}_{\mathrm{COO}-}$ & \\
\hline & 2.295 & 176 & $2 \mathrm{~N}_{\mathrm{im}}, \mathrm{O}_{\mathrm{COO}-}$ & \\
\hline & 2.335 & 146 & $\mathrm{NH}_{2}, \mathrm{~N}_{\mathrm{im}}, \mathrm{O}_{\mathrm{COO}-}$ & \\
\hline \multirow[t]{2}{*}{$4.5-5.3$} & 2.295 & 176 & $2 \mathrm{~N}_{\mathrm{im}}, \mathrm{O}_{\mathrm{COO}-}$ & -0.515 \\
\hline & 2.250 & 185 & $\mathrm{NH}_{2}, \mathrm{~N}_{\mathrm{Im}}, \mathrm{N}^{-}, \mathrm{O}_{\mathrm{COO}-}$ & -0.592 \\
\hline $5.3-8.2$ & 2.224 & 186 & $\mathrm{NH}_{2}, \mathrm{~N}_{\mathrm{Im}}, 2 \mathrm{~N}^{-}$ & -0.585 \\
\hline 9.2 & 2.195 & 203 & $\mathrm{~N}_{\mathrm{im}}, 3 \mathrm{~N}^{-}$ & -0.550 \\
\hline 10.5 & 2.195 & 201 & $\mathrm{~N}_{\mathrm{im}}, 3 \mathrm{~N}^{-}$ & -0.550 \\
\hline \multicolumn{5}{|c|}{$C u(I I)-A n g 1-17$ 2:1 } \\
\hline \multirow[t]{2}{*}{$5.2-6.2$} & 2.245 & 186 & $\mathrm{NH}_{2}, \mathrm{~N}^{-}, \mathrm{O}_{\mathrm{COO}-}$ & -0.590 \\
\hline & 2.295 & 176 & $2 \mathrm{~N}_{\mathrm{im}}, \mathrm{O}_{\mathrm{COO}-}$ & -0.515 \\
\hline \multirow[t]{2}{*}{$6.2-7.9$} & 2.228 & 184 & $\mathrm{~N}_{\mathrm{Im}}, 3 \mathrm{~N}^{-}$ & -0.534 \\
\hline & 2.208 & 187 & $\mathrm{NH}_{2}, \mathrm{Nim}, 2 \mathrm{~N}^{-}$ & -0.618 \\
\hline 8.5 & 2.209 & 194 & & \\
\hline $9.2-11$ & 2.196 & 205 & $\mathrm{~N}_{\mathrm{im}}, 3 \mathrm{~N}^{-} \mathrm{NH}_{2}, 3 \mathrm{~N}^{-}$ & -0.571 \\
\hline \multicolumn{5}{|c|}{$C u(I I)-A c A n g 1-17$ 1:1 } \\
\hline \multirow[t]{3}{*}{3.8} & 2.424 & 124 & $6 \mathrm{H}_{2} \mathrm{O}$ & \\
\hline & 2.332 & 158 & $\mathrm{~N}_{\mathrm{im}}, \mathrm{O}_{\mathrm{COO}-}$ & -0.209 \\
\hline & 2.295 & 176 & $2 \mathrm{~N}_{\mathrm{im}}, \mathrm{O}_{\mathrm{COO}-}$ & -0.515 \\
\hline 5.0 & 2.295 & 176 & $2 \mathrm{~N}_{\mathrm{im}}, \mathrm{O}_{\mathrm{COO}-}$ & \\
\hline \multirow[t]{2}{*}{6.0} & 2.266 & 180 & $2 \mathrm{~N}_{\mathrm{im}}, \mathrm{N}^{-}$ & -0.594 \\
\hline & 2.212 & 196 & $2 \mathrm{~N}_{\mathrm{im}}, 2 \mathrm{~N}^{-}$ & -0.662 \\
\hline $6.9-8.1$ & 2.212 & 196 & $2 \mathrm{~N}_{\mathrm{im}}, 2 \mathrm{~N}^{-}$ & -0.656 \\
\hline 9.3 & 2.206 & 200 & $\mathrm{~N}_{\mathrm{im}}, 3 \mathrm{~N}^{-}$ & -0.580 \\
\hline 10.8 & 2.199 & 205 & $\mathrm{~N}_{\mathrm{im}}, 3 \mathrm{~N}^{-}$ & -0.615 \\
\hline \multicolumn{5}{|c|}{$C u(I I)-A c A n g 1-17$ 2:1 } \\
\hline \multirow[t]{2}{*}{$4.3-5.6$} & 2.332 & 158 & $\mathrm{~N}_{\mathrm{im}}, \mathrm{O}_{\mathrm{COO}-}$ & \\
\hline & 2.290 & 170 & $\mathrm{~N}_{\mathrm{im}}, \mathrm{N}^{-}, \mathrm{O}_{\mathrm{COO}-}$ & \\
\hline \multirow[t]{2}{*}{6.4} & 2.220 & 184 & $\mathrm{~N}_{\mathrm{im}}, 2 \mathrm{~N}^{-}$ & -0.565 \\
\hline & 2.200 & 190 & $\mathrm{~N}_{\mathrm{im}}, 3 \mathrm{~N}^{-}$ & -0.631 \\
\hline \multirow[t]{2}{*}{7.6} & 2.205 & 190 & $\mathrm{~N}_{\mathrm{im}}, 3 \mathrm{~N}^{-}$ & -0.631 \\
\hline & 2.195 & 198 & $\mathrm{~N}_{\mathrm{im}}, 3 \mathrm{~N}^{-}$ & -0.582 \\
\hline $8.5-9.5$ & 2.190 & 198 & $\mathrm{~N}_{\mathrm{im}}, 3 \mathrm{~N}^{-}$ & \\
\hline \multirow[t]{2}{*}{10.8} & 2.195 & 205 & $\mathrm{~N}_{\mathrm{im}}, 3 \mathrm{~N}^{-}$ & \\
\hline & 2.185 & 195 & $\mathrm{~N}_{\mathrm{im}}, 3 \mathrm{~N}^{-}$ & \\
\hline
\end{tabular}




\subsection{Voltammetric Study on Cu(II)-Ang1-17 System (M/L 1:1)}

The electrochemical data were collected at different $\mathrm{pH}$ values between 3.5 and 11.0, covering the range of copper complex species formation. The formal redox potentials together with the ESR parameters are reported in Table 3.

Square wave voltammogram (SWV) carried out on a solution of Cu-Ang1-17 at $\mathrm{pH}=4.5\left(\mathrm{M} / \mathrm{L} 1: 1, \mathrm{I}=0.1 \mathrm{M} \mathrm{KNO}_{3}\right)$ showed a peak at $-0.610 \mathrm{~V}$ (beside the presence of the $\mathrm{Cu}$ (II) hexaaquo ion peak) with a shoulder at $-0.495 \mathrm{~V}$ (Figure $5 \mathrm{a})$. The deconvolution of the voltammetric curve by using PeakFit 4.0 program (Jandel) gave as result two peaks centered at $-0.592 \mathrm{~V}$ and $-0.509 \mathrm{~V}$, thus giving evidence of two kinds of coordination polyhedra. The quite negative value of the former potential value suggests the formation of a distorted octahedral $\mathrm{Cu}$ (II) coordination polyhedron, attributable to the $\mathrm{NH}_{2}, \mathrm{~N}_{\text {Im }}$, $\mathrm{N}^{-}, \mathrm{O}_{\mathrm{COO}}$ donor set. In fact, despite of the involvement of only two nitrogen atoms in the $\mathrm{Cu}(\mathrm{II})$ coordination, the strong basicity of the amino moiety must be considered. In addition, the coordination of a deprotonated amide and a negative charged carboxylate oxygen atom increases the charge density of the $\mathrm{Cu}$ (II) atom, hence hindering the reduction process. All these factors concur to strengthen the ligand field, which means that a quite large absolute value of $A_{\mid ।}\left(185 \times 10^{-4} \mathrm{~cm}^{-1}\right)$ and a quite negative value for the reduction process $(-0.592 \mathrm{~V})$ of $\mathrm{Cu}(\mathrm{II})$ is observed. The other deconvoluted peak (centered at $-0.515) \mathrm{V}$ can be assigned to $2 \mathrm{~N}_{\mathrm{Im}}, \mathrm{O}_{\mathrm{COO}}$ - donor set, and the formal redox potential value is indicative of a distorted tetragonal chromophore [55].
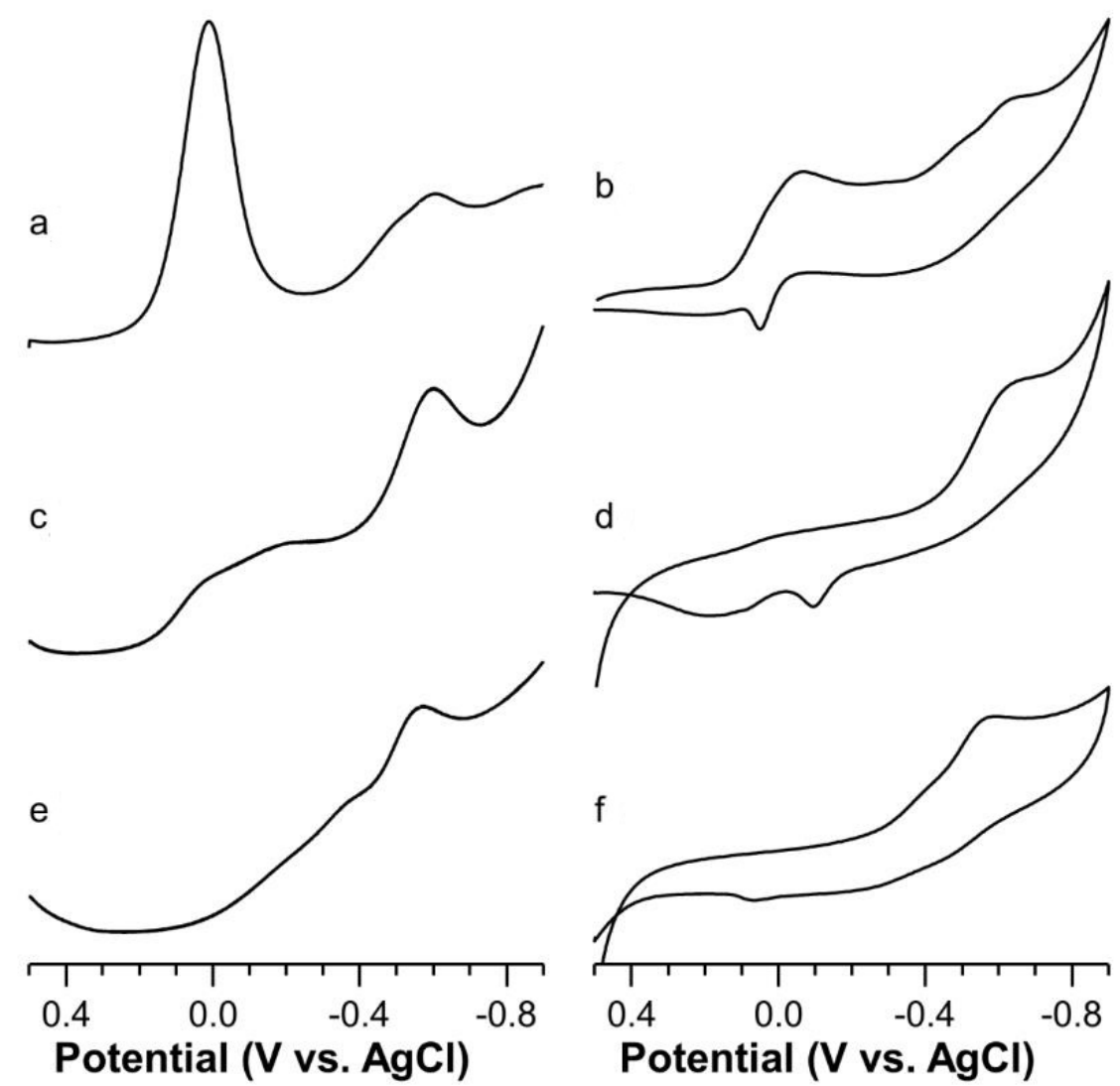

Figure 5. Square wave (left) and cyclic (right) voltammograms of $\mathrm{Cu}(\mathrm{II})$-Ang1-17 system $\left(\mathrm{C}_{\mathrm{L}}=5 \times 10^{-4} \mathrm{M}, \mathrm{M}: \mathrm{L}\right.$ 0.9:1, $\left.\mathrm{KNO}_{3} 0.1 \mathrm{M}\right)$ in aqueous solution as function of the $\mathrm{pH}:(\mathbf{a}, \mathbf{b}) 4.5$; (c,d) 7.3 ; (e,f) 11.0.

The cyclic voltammogram (CV) showed two cathodic peaks (Figure 5b); the first can be assigned to $\mathrm{Cu}(\mathrm{II})$ hexaaquo ion reduction at about $-0.045 \mathrm{~V}$, whereas the other peak, at $-0.625 \mathrm{~V}$ with a shoulder at $-0.494 \mathrm{~V}$, is due to the reduction processes of the two $\mathrm{Cu}$ (II) coordination species. The re-oxidation anodic peaks of these latter processes are not 
clearly separated but coalesce into a single broad peak having a mean potential of $-0.446 \mathrm{~V}$. Overall, these processes can be considered quasi-reversible.

On raising the $\mathrm{pH}$ toward neutrality, the potential peak intensities due to $\mathrm{Cu}$ (II) hexaaquo ion electrochemical processes progressively decrease and disappear, whereas those of the two above described complex species increase progressively and show broad peaks due to different individual contributions.

At physiological $\mathrm{pH}$ values, and up to $\mathrm{pH}=8$, SWV traces present a well pronounced peak centered at $-0.585 \mathrm{~V}$ (Figure $5 \mathrm{c}$ ) characteristic of strong ligand field due to a slightly distorted $\mathrm{CuN} 4$ chromophore. This hypothesis agrees with ESR data assigned to $\left[\mathrm{CuLH}_{-1}\right]$ species.

$\mathrm{CV}$ scans at $\mathrm{pH}=7.3$ showed a cathodic peak at $-0.615 \mathrm{~V}$ (Figure $5 \mathrm{~d}$ ) which is associated with the anodic reoxidation at $-0.490 \mathrm{~V}$. The peak-to-peak separation is about $130 \mathrm{mV}$ and the $\mathrm{i}_{\mathrm{a}} / \mathrm{i}_{\mathrm{c}}$ ratio is about 0.5 , which means that this process can also be considered quasi-reversible.

From $\mathrm{pH} 8$ to $\mathrm{pH} 10$ and higher, the SWV peak centered at $-0.585 \mathrm{~V}$ progressively moves towards the $\mathrm{E}_{\mathrm{f}}^{\circ}$ value of $-0.550 \mathrm{~V}$ at $\mathrm{pH}=11$ (Figure $5 \mathrm{e}$ ). This potential shift corroborates the distortion of the $\mathrm{Cu}(\mathrm{II})$ coordination plane already seen in the ESR measurements. The CVs show a cathodic peak at $-0.555 \mathrm{~V}$ (Figure $5 \mathrm{f}$ ), but the corresponding anodic peak is nearly absent. This behavior may account for a rearrangement of the coordination environment due to the different demand of $\mathrm{Cu}(\mathrm{I})$, upon reduction of $\mathrm{Cu}(\mathrm{II})$, i.e., diagonal or trigonal geometries.

\subsection{Voltammetric Study on Cu(II)-AcAng1-17 System (M/L 1:1)}

A square wave voltammogram (SWV) carried out on a solution of Cu-AcAng1-17 at $\mathrm{pH}=4.5\left(\mathrm{M} / \mathrm{L}=1, \mathrm{I}=0.1 \mathrm{M} \mathrm{KNO}_{3}\right)$ evidenced a peak at about $-0.585 \mathrm{~V}$ and a smaller peak $(-0.209 \mathrm{~V})$ at the foot of the $\mathrm{Cu}$ (II) hexaaquo ion (Figure 6a). The small peak may be attributed to the coordination of an imidazole moiety to the $\mathrm{Cu}(\mathrm{II})$ with a partial contribution of the carboxylate (about $20 \%$ protonated, $\mathrm{pK}=3.90$ ) [45].

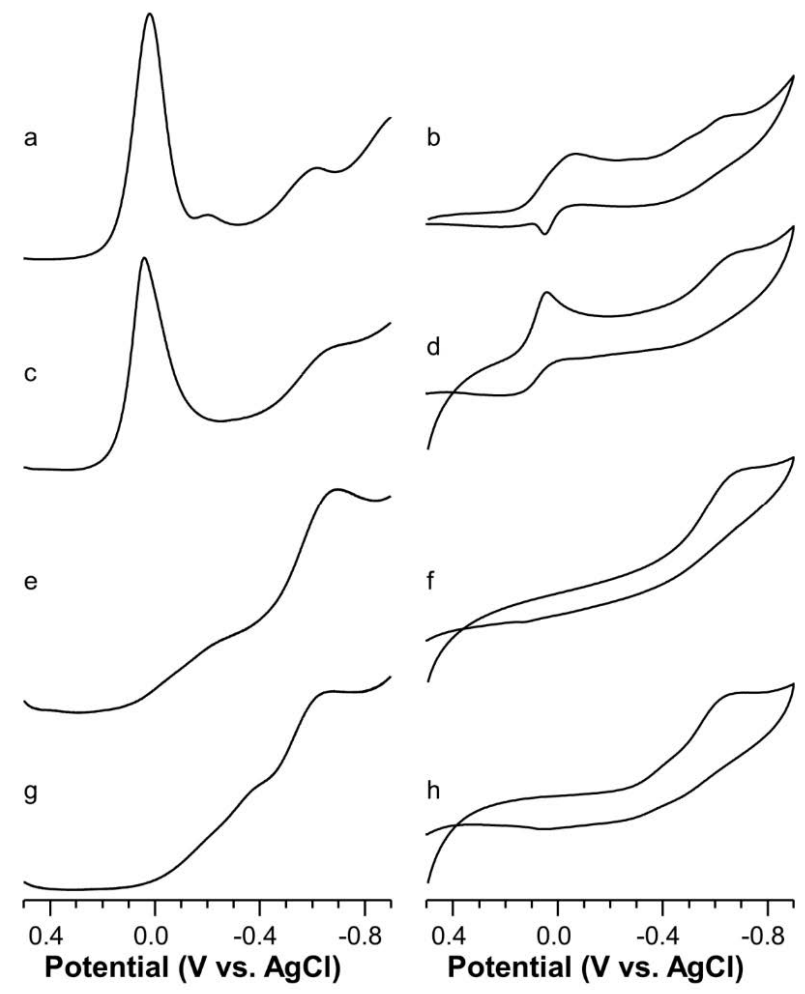

Figure 6. Square wave (left) and cyclic (right) voltammograms of $\mathrm{Cu}(\mathrm{II})$-AcAng1-17 system $\left(\mathrm{C}_{\mathrm{L}}=5 \times 10^{-4} \mathrm{M}, \mathrm{M}: \mathrm{L} 0.9: 1, \mathrm{KNO}_{3} 0.1 \mathrm{M}\right)$ in aqueous solution as function of the $\mathrm{pH}:(\mathbf{a}, \mathbf{b}) 4.5$; (c,d) $6.0 ;(\mathbf{e}, \mathbf{f}) 8.0 ;(\mathbf{g}, \mathbf{h}) 11.0$. 
The deconvolution of the broad peak resulted in two peaks: $-0.515 \mathrm{~V}$ and $-0.597 \mathrm{~V}$. The value of $-0.515 \mathrm{~V}$ is that found for the $2 \mathrm{~N}_{\mathrm{Im}}, \mathrm{O}_{\mathrm{COO}-}$ donor set, whereas the more negative value may be attributed to the coordination by at least two histidines. These processes could be related to different isomers previously found for $\left[\mathrm{CuLH}_{4}\right]$ species [45]. The formal potential of -0.597 is nearly the same as that attributed to the $2 \mathrm{~N}_{\mathrm{Im}}, \mathrm{N}^{-}$ coordination environment at higher $\mathrm{pH}$ values (Table 3 ).

$\mathrm{CV}$ showed a cathodic peak due to the $\mathrm{Cu}(\mathrm{II})$ reduction, followed by two cathodic reduction peaks at -0.237 and $-0.600 \mathrm{~V}$ (Figure $6 \mathrm{~b}$ ). Only a small but broad anodic peak can be associated with this latter reduction.

The SWV run at $\mathrm{pH}=6$ showed a broad peak positioned at -0.642 (Figure $6 \mathrm{c}$ ) and a sharp peak at about $+0.040 \mathrm{~V}$. The intensity of this latter peak, together with the triangular shape of the associate cathodic peak in the CV experiment (Figure 6d), suggests the occurrence of an adsorption process in addition to the reduction process of residual uncomplexed $\mathrm{Cu}$ (II) ion (as expect from distribution species diagram). The deconvolution of the broad peak resulted in two peaks centered at $-0.594 \mathrm{~V}$ and $-0.662 \mathrm{~V}$. The first value was assigned to $2 \mathrm{~N}_{\mathrm{Im}}, \mathrm{N}^{-}$coordination whereas the more negative value can be ascribed to $4 \mathrm{~N}$ coordination, i.e., $2 \mathrm{~N}_{\mathrm{Im}}, 2 \mathrm{~N}^{-}$in which a further deprotonated amide nitrogen atom takes the place of carboxylate oxygen atom.

In the $\mathrm{pH}$ range from 7 to 8 , a peak is only detected in the SWV traces. The associated $\mathrm{E}_{\mathrm{f}}^{\circ}$ value is $-0.656 \mathrm{~V}$ (Figure 6e) is well-suited to a planar $\mathrm{Cu}(\mathrm{II})$ coordination environment formed by four nitrogen donor atoms, which is in good agreement with the ESR spectra. In addition, the CV voltammograms exhibit a single reduction (cathodic) peak at $-0.660 \mathrm{~V}$ and its associated anodic wave is at $-0.477 \mathrm{~V}$ (Figure $6 \mathrm{f}$ ).

Finally, at the most alkaline $\mathrm{pH}$ values the $\mathrm{E}_{\mathrm{f}}^{\circ}$ value shifts towards $-0.615 \mathrm{~V}$ (Figure $6 \mathrm{~g}$ ). This value is still in agreement with a four-nitrogen coordination environment, but the positive shift indicates a distortion of the plane.

\subsection{Voltammetric Study on Cu(II) with Ang1-17 or AcAng1-17 Systems (M/L 2:1)}

The addition of two equivalents of $\mathrm{Cu}$ (II) ion to both peptides resulted in the formation of different coordination environments because of the distribution of the metal ions among different anchoring points.

The SWV voltammograms run on $\mathrm{Cu}(\mathrm{II})$-Ang1-17 system (M/L 2:1) at $\mathrm{pH}=6$ show two main peaks (Figure 7a). The first peak may be due to the presence of residual $\mathrm{Cu}$ (II) uncomplexed ions, whereas the second fairly broad peak is placed at $-0.571 \mathrm{~V}$. The deconvolution of the broad peak at $-0.571 \mathrm{~V}$ unveils the presence of two peaks having $\mathrm{E}_{\mathrm{f}}^{\circ}$ values of $-0.520 \mathrm{~V}$ and $-0.590 \mathrm{~V}$, due to the reduction of two different $\mathrm{CuN}_{2} \mathrm{O}_{2}$ chromophores: the first is formed by $2 \mathrm{~N}_{\mathrm{im}}, \mathrm{O}_{\mathrm{COO}-}, \mathrm{H}_{2} \mathrm{O}$ donor set, whereas the most negative peak potential can be ascribed to $\mathrm{NH}_{2}, \mathrm{~N}^{-}, \mathrm{O}_{\mathrm{COO}-}, \mathrm{H}_{2} \mathrm{O}$.

At almost physiological value, the SWV trace presents a main broad peak centered at $-0.585 \mathrm{~V}$ (Figure 7c). The outcome of the deconvolution of the latter wave gave two peaks centered at $-0.534 \mathrm{~V}$ and $-0.618 \mathrm{~V}$, which suggest the presence of distorted $\mathrm{N}_{\mathrm{Im}}, 3 \mathrm{~N}^{-}$and $\mathrm{NH}_{2}, 2 \mathrm{~N}^{-}, \mathrm{N}_{\text {Im }}$ donor sets, respectively. This last coordination scenario is evident at higher $\mathrm{pH}$ values and the $\mathrm{E}_{\mathrm{f}}^{\circ}$ value moves towards the $-0.571 \mathrm{~V}$ (Figure $7 \mathrm{e}$ ). The more positive $\mathrm{E}_{\mathrm{f}}^{\circ}$ value found at high $\mathrm{pH}$ confirms the distortion of the four nitrogen donor atoms as also inferred by the high values of absorptivity found at high $\mathrm{pH}$ values. The formation of more distorted structural isomers cannot be ruled out as a small shoulder can be seen at $-0.355 \mathrm{~V}$ on the SWV trace. 


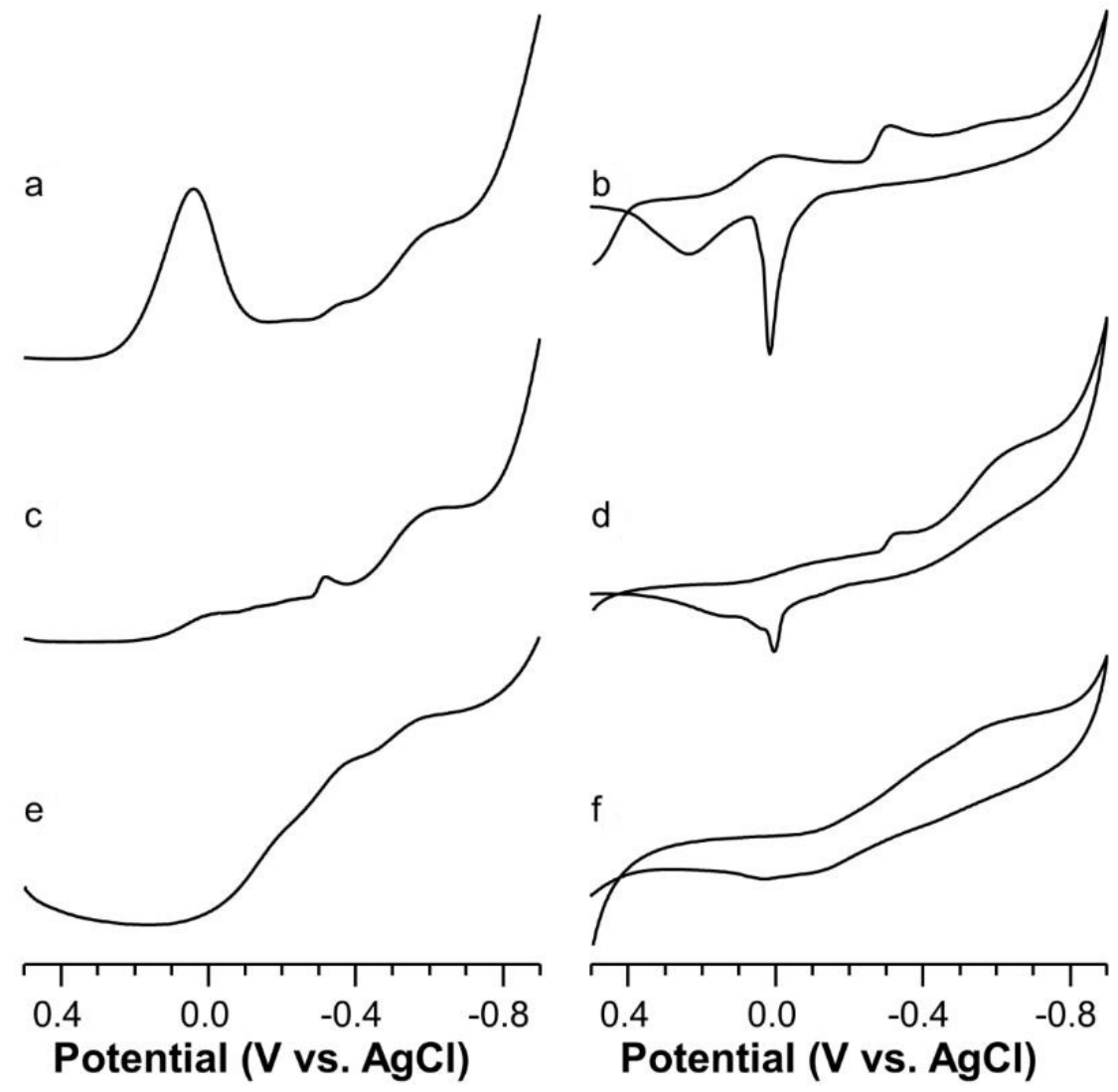

Figure 7. Square wave (left) and cyclic (right) voltammograms of $\mathrm{Cu}(\mathrm{II})$-Ang1-17 system $\left(\mathrm{C}_{\mathrm{L}}=5 \times 10^{-4} \mathrm{M}, \mathrm{M}: \mathrm{L} 1.8: 1, \mathrm{KNO}_{3} 0.1 \mathrm{M}\right)$ in aqueous solution as function of the $\mathrm{pH}:(\mathbf{a}, \mathbf{b}) 6.0$; (c,d) $7.3 ;(\mathbf{e}, \mathbf{f})$ 11.0.

Concerning the AcAng1-17 peptide, the amino group acetylation hinders its coordination ability and the number of preferred anchoring points for $\mathrm{Cu}$ (II) reduces essentially to the two histidine residues. As a consequence, the number of species present in the solution drastically decreases.

At $\mathrm{pH}=6.4$, the SWV trace present minor redox active species and some residual free copper ions and a broad peak at $-0.610 \mathrm{~V}$ (Figure $8 \mathrm{a}$ ). At this $\mathrm{pH}$ value both $\left[\mathrm{Cu}_{2} \mathrm{LH}_{-1}\right]$ and $\left[\mathrm{Cu}_{2} \mathrm{LH}_{-3}\right]$ species are present, and their formal potentials values were estimated by deconvolution, the outcomes of which were $-0.565 \mathrm{~V}$ and $-0.631 \mathrm{~V}$, respectively.

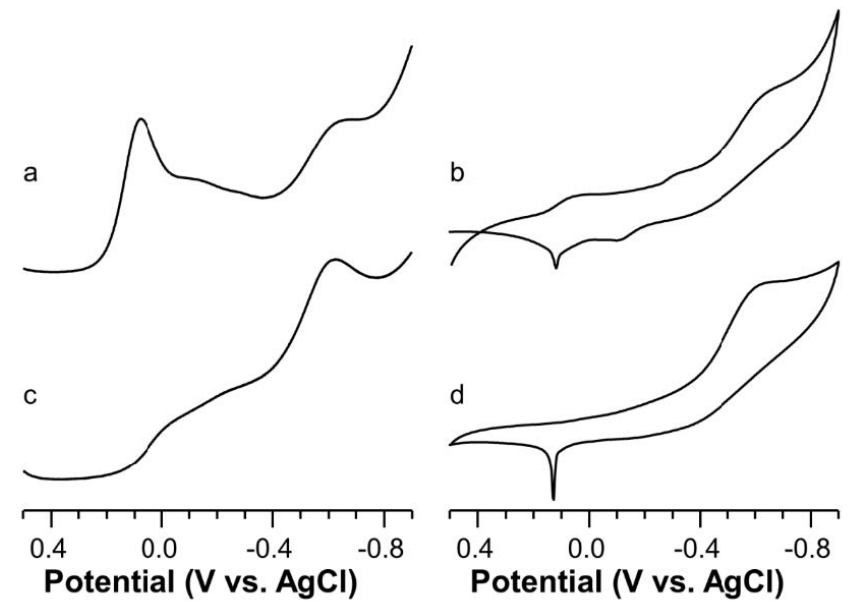

Figure 8. Square wave (left) and cyclic (right) voltammograms of $\mathrm{Cu}$ (II)-AcAng1-17 system $\left(\mathrm{C}_{\mathrm{L}}=5\right.$ $\left.\times 10^{-4} \mathrm{M}, \mathrm{M}: \mathrm{L} 1.8: 1, \mathrm{KNO}_{3} 0.1 \mathrm{M}\right)$ in aqueous solution as function of the $\mathrm{pH}:(\mathbf{a}, \mathbf{b}) 6.4 ;(\mathbf{c}, \mathbf{d})$ 7.6. 
A quite similar peak centered at $-0.600 \mathrm{~V}$ (Figure 8c) was obtained at $\mathrm{pH}=7.6$ where only $\left[\mathrm{Cu}_{2} \mathrm{LH}_{-3}\right]$ species is present with two very similar coordination environments showing different degrees of distortion from planarity, i.e., $\mathrm{E}_{\mathrm{f}}^{\circ}$ values of $-0.582 \mathrm{~V}$ and $-0.631 \mathrm{~V}$, obtained by peak deconvolution.

\subsection{Peptides Effect on Intracellular Copper Contents in SH-SY5Y Cell Line}

Neuroblastoma cell lines SH-SY5Y were stained with copper sensor1 (CS1), an intracellular fluorescent probe of monovalent copper [34]. The red emission of the CS1 fluorophore component due to the BODIPY group, is enhanced when the $\mathrm{Cu}^{+}$chelator moiety binds to the intracellular copper. Confocal microscopy imaging was used to scrutinize the cells and investigate if the whole ANG protein (wild-type and recombinant isoforms), as well as Ang1-17 and AcAng1-17 peptides, could influence copper cellular content. The experiments were performed in the presence or absence of copper ions.

The histogram in Figure 9 shows the response to the $\mathrm{Cu}^{+}$reporter for the different treatment conditions.

(a) ctrl

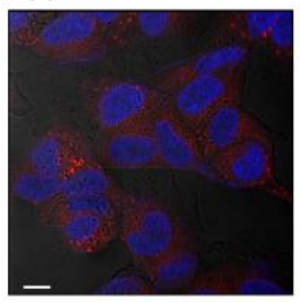

(b) Ang1-17

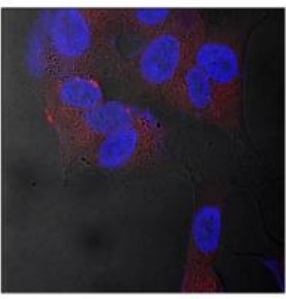

(c) AcAng1-17

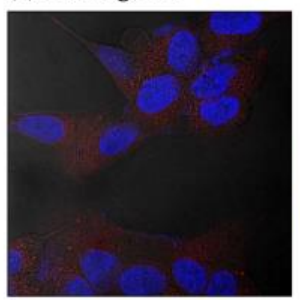

(d) wtANG

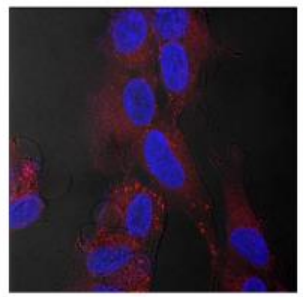

(e) rANG

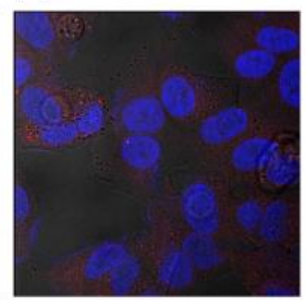

(f)

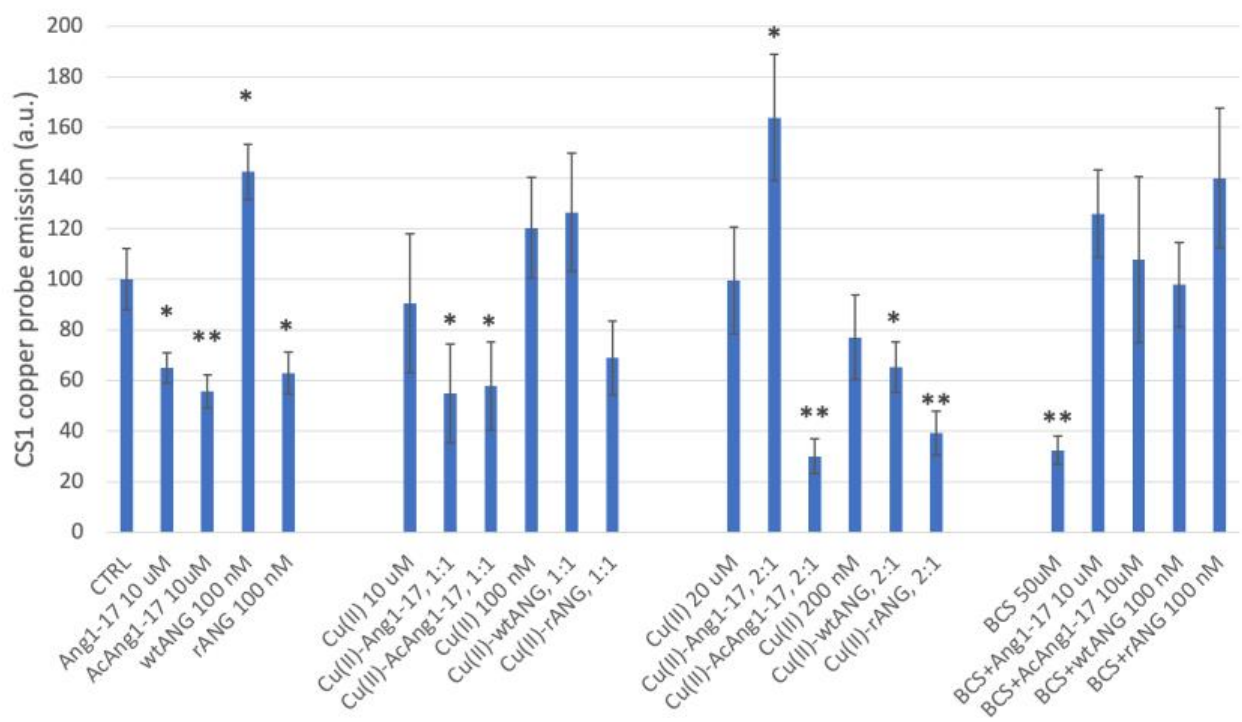

Figure 9. Representative confocal microscopy merged micrographs of fluorescence channels (in blue, nuclear staining, $\lambda_{\text {ex } / \mathrm{em}}=405 / 425-450 \mathrm{~nm}$; in red, CS1-copper probe, $\lambda_{\mathrm{ex} / \mathrm{em}}=543 / 550-600 \mathrm{~nm}$ ) and optical bright field (in grey) of SHSY5Y cells untreated (a, negative control) and after 90 min of treatment with: (b) $10 \mu \mathrm{M}$ Ang1-17, (c) 10 $\mu \mathrm{M}$ AcAng1-17, (d) $100 \mathrm{nM}$ wtANG, and (e) $100 \mathrm{nM}$ rANG. Scale bar $=10 \mu \mathrm{m}$. In (f) is shown the quantitative analysis of CS1-copper probe emission intensity for the cells treated as follows (four blocks from left to right): in basal medium, untreated or $10 \mu \mathrm{M}$ peptide-/100 nM protein-treated cells; in $\mathrm{CuSO}_{4}$-supplemented medium, equimolar copper/peptide or copper/protein ratio; in $\mathrm{CuSO}_{4}$-supplemented medium, 2:1 copper/peptide or copper/protein molar ratio; in copper deprived medium by pretreatment with BCS extracellular copper chelator, in the absence or presence of $10 \mu \mathrm{M}$ peptides $/ 100 \mathrm{nM}$ proteins. Bars represent means \pm SEM of at least 3 experiments; $\left({ }^{*}\right)=p<0.05,\left({ }^{* *}\right)=p<0.01$, vs. CTRL (untreated cells in basal medium) (Student's $t$-test).

It is important to note that in the series of cellular treatments in basal medium, incubation with both free peptides, Ang1-17 or AcAng1-17, induced a decrease in red 
fluorescence inside cells. These data suggest that both peptides are able to bind the copper ions present in the basal medium, which can reach micromolar concentration [56], and can shift the balance of copper from inside the cell to outside. On the other hand, the incubation with wtANG showed a strong increase in intracellular copper fluorescence, while treatment with rANG induced a significant decrease in intracellular copper compared to the negative control of untreated cells.

In a parallel series of cell treatments, in order to have control over the very variable trace copper in the medium, typically ranging from submicromolar to a few micromolar units [56], we used the BCS extracellular copper chelator [57,58]. The histograms in Figure $9 \mathrm{f}$ show that, besides the reference pretreatment with $50 \mu \mathrm{M}$ BCS, no significant changes in the intracellular copper could be detected for any of the treatments, either with the peptides or the proteins.

Interestingly, in the copper-supplemented medium, after cell incubation with equimolar copper/peptide or copper/protein concentrations, only in the case of the treatments with the peptides was a decrease in CS1 intensity in the cytosol still detected. Moreover, in the case of an excess of copper, at 2:1 molar ratio, while the amount of copper inside the cell increased upon the treatment with Ang1-17, a significant decrease was detected after incubation with AcAng1-17, wtANG or rANG.

\section{Discussion}

The ability to chelate copper(II) ions and the characterization of the species formed with Ang1-17 and AcAng1-17 have been investigated by using M/L 1:1 and 2:1. Potentiometric, spectroscopic and voltammetric techniques are of great help to understand which species form as a function of $\mathrm{pH}$ and which donor atoms are involved in each complex species. In particular, ESR spectroscopy also allows the characterization of copper complexes geometry that determines the redox potential of the $\mathrm{Cu}(\mathrm{II}) / \mathrm{Cu}(\mathrm{I})$ pair, a critical parameter in determining the efficiency of most biochemical reactions involving copper $[59,60]$. In a previous work, we determined the species formed by the peptides Ang(1-17) and AcAng1-17 with $\mathrm{Cu}(\mathrm{II})$ ion at M/L 1:1 by means of potentiometric studies [45]. Specifically, we found that the Ang1-17 peptide started to complex $\mathrm{Cu}$ (II) forming $[\mathrm{CuLH}]$ species, where the amino group acts as main anchoring site via its nitrogen atom. The coordination environment of the chromophore is completed by a deprotonated amide nitrogen atom, the Asp carboxylic oxygen and a water molecule.

Another important fact to note is that a second possible concurrent anchoring site would be the imidazole nitrogen of His8 which, together with the histidine amide nitrogen, the Asp15 carboxylic oxygen and a water molecule, form a very similar chromophore. Potentiometry does not allow us to highlight the presence of structural isomers, since it measures macroconstants, whereas ESR and voltammetric measurements may show the presence of isomers if they have a different coordination environment.

The ESR spectra run on a frozen solution of $\mathrm{Cu}$ (II)-Ang1-17 system in the 3.5-3.9 $\mathrm{pH}$ range showed the presence of several patterns due to different species and residual $\mathrm{Cu}$ (II) hexaaquo ion. The first set of parameters $\left(\mathrm{g}_{||}=2.335, \mathrm{~A}_{||}=146 \times 10^{-4} \mathrm{~cm}^{-1}\right.$ ) can be attributed to the $\mathrm{CuN}_{2} \mathrm{O}_{2}$ chromophore containing the amino group, an imidazole nitrogen and a carboxylic oxygen atoms in a distorted octahedral polyhedron [61]. The second set of parameters $\left(\mathrm{g}_{||}=2.295, \mathrm{~A}_{||}=176 \times 10^{-4} \mathrm{~cm}^{-1}\right)$ can be assigned to a chromophore formed by two imidazole nitrogen atoms and a deprotonated carboxylate (Asp), as previously reported [62,63], despite of the lack of a close sequence proximity of the two histidine residues.

On raising the $\mathrm{pH}$ value to 4.5 , the main ESR active species is characterized by $\mathrm{g}_{||}=2.250$ and $\mathrm{A}_{||}=185 \times 10^{-4} \mathrm{~cm}^{-1}$. This species can be assigned to [CuL] species, where the metal is coordinated by $\mathrm{NH}_{2}, \mathrm{~N}_{\mathrm{im}}, \mathrm{N}^{-}, \mathrm{O}_{\mathrm{COO}-}$ chromophore, i.e., the amino group, an imidazole ring nitrogen atom, a deprotonated amide and a carboxylic oxygen atoms [45,64], hence forming a distorted $\mathrm{CuN}_{3} \mathrm{O}$ chromophore. This coordination features are confirmed by the presence of a strong negative peak at $-0.592 \mathrm{~V}$ in the voltammetric 
curve. The formation of this species is also supported by the coordination environment of the $\left[\mathrm{CuLH}_{-1}\right]$ species formed in the 5.3-8.2 $\mathrm{pH}$ range. At $\mathrm{pH}$ values close to neutral, such a complex is fully formed by the deprotonation of an additional amide nitrogen atom replacing the carboxylic oxygen atom, i.e., $\mathrm{NH}_{2}, \mathrm{~N}_{\mathrm{Im}}, 2 \mathrm{~N}^{-}$. This $\mathrm{CuN}_{4}$ chromophore has a slightly distorted octahedral geometry.

Notably, for a four-nitrogen in-plane a higher $\mathrm{A}_{||}$value is expected associated with a more negative value of $\mathrm{E}_{\mathrm{f}}^{\circ}$. Instead, this deprotonation caused only a modest increase in the $A_{||}$value, indicating that a significant distortion of the coordination plane occurred. This is supported by a well pronounced peak centered at $-0.585 \mathrm{~V}$ in the SWV trace, confirming the presence of a slightly distorted $\mathrm{CuN}_{4}$ chromophore [45].

Above $\mathrm{pH}=9.2$ only a single species characterized by $\mathrm{g}_{||}=2.195, \mathrm{~A}_{||}=203 \times 10^{-4} \mathrm{~cm}^{-1}$ was detected by ESR spectrometry. These magnetic parameters are consistent with the presence of $\left[\mathrm{CuLH}_{-2}\right]$ species which formed after deprotonation of a third amide nitrogen atom. This latter donor atom replaces the amino moiety so as the chromophore is always a distorted $\mathrm{CuN}_{4}$ but a stronger ligand field is experienced by the metal ion, as confirmed by the increase in the hyperfine coupling constant and the decrease in the value of $d-d$ band. Nevertheless, a higher $A_{||}$value would also be expected in this case; hence some distortion of the coordination plane persists, as also indicated by the $\varepsilon$ increase from 106 to $130 \mathrm{M}^{-1} \mathrm{~cm}^{-1}$ on going from $\mathrm{pH} 8.5$ to 11.0 [45]. The value of $-0.550 \mathrm{~V}$ obtained by SWV is more positive with respect to previous species $(-0.585 \mathrm{~V})$ and is in line with the trend shown by ESR spectroscopy.

The formation of isomers observed when one equivalent of copper(II) ion is added to the Ang1-17 peptide gave us a clue about the its ability to accept up to two equivalents of the metal.

No attempt to characterize the $\left[\mathrm{Cu}_{2} \mathrm{LH}\right]$ complex species using the ESR data were performed because of the large amount of copper(II) hexaaquo ion that is present at very acidic $\mathrm{pH}$ values. Additionally, the $\left[\mathrm{Cu}_{2} \mathrm{~L}\right]$ complex species was not clearly recorded at low temperature $(150 \mathrm{~K})$. Actually, at the $\mathrm{pH}$ value of 5.5 an ESR pattern attributable to the subsequent $\left[\mathrm{Cu}_{2} \mathrm{LH}_{-1}\right]$ species is probably found because the low temperature favors its formation over the $\left[\mathrm{Cu}_{2} \mathrm{~L}\right]$ species. The Hamiltonian parameters obtained for the $\left[\mathrm{Cu}_{2} \mathrm{LH}_{-1}\right]$ species (obtained from simulation, i.e., $\mathrm{g}_{||}=2.245, \mathrm{~A}_{||}=186 \times 10^{-4} \mathrm{~cm}^{-1}$ and $\mathrm{g}_{||}=2.295, \mathrm{~A}_{||}=176 \times 10^{-4} \mathrm{~cm}^{-1}$ ) can be assigned to two coordination environments formed by $\mathrm{NH}_{2}, \mathrm{~N}^{-}, \mathrm{O}_{\mathrm{COO}-}$ and $2 \mathrm{~N}_{\mathrm{Im}}, \mathrm{O}_{\mathrm{COO}-}$ donor sets, respectively, analogously to those obtained for $[\mathrm{CuLH}]$ isomers (at metal-to-ligand ratio of 1:1). The presence of two metal centers with two different coordination environments is confirmed by the deconvolution of the broad peak at $-0.571 \mathrm{~V}$ detected in the SWV trace. There are two peaks with $\mathrm{E}_{\mathrm{f}}^{\circ}$ values of $-0.590 \mathrm{~V}$ assigned to a $\mathrm{Cu}\left(\mathrm{NH}_{2}, \mathrm{~N}^{-}, \mathrm{O}_{\mathrm{COO}-}\right)$ chromophore, and of $-0.515 \mathrm{~V}$ assigned to $\mathrm{Cu}\left(2 \mathrm{~N}_{\mathrm{Im}}, \mathrm{O}_{\mathrm{COO}-}\right)$ chromophore.

The main complex species $\left[\mathrm{Cu}_{2} \mathrm{LH}_{-3}\right],\left[\mathrm{Cu}_{2} \mathrm{LH}_{-4}\right]$ and $\left[\mathrm{Cu}_{2} \mathrm{LH}_{-5}\right]$ are present in the 6-8 pH range. The corresponding ESR spectra showed slightly broadened features and the parameters directly extracted are $\mathrm{g}_{||}=2.218, \mathrm{~A}_{||}=191 \times 10^{-4} \mathrm{~cm}^{-1}$. The ESR spectra were satisfactorily simulated by using two sets of Hamiltonian parameters, i.e., $\mathrm{g}_{||}=2.228, \mathrm{~A}_{||}=184 \times 10^{-4} \mathrm{~cm}^{-1}$ and $\mathrm{g}_{||}=2.208, \mathrm{~A}_{||}=187 \times 10^{-4} \mathrm{~cm}^{-1}$. Notably, the

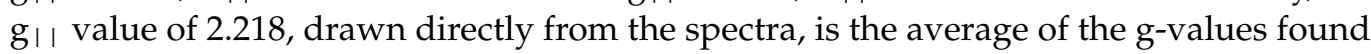
in the spectral simulation. A variety of coordination environments was also found for copper(II) complexes with 1-16 fragments of $\beta$-amyloid [35]. In particular, the murine Ac-1-16M fragment forms a species having $g_{||}=2.233, \mathrm{~A}_{||}=187 \times 10^{-4} \mathrm{~cm}^{-1}$, which were attributed to $\mathrm{N}_{\mathrm{Im}}, 2 \mathrm{~N}^{-}, \mathrm{H}_{2} \mathrm{O}$ donor set [61], and these values are close to the first couple of parameters obtained by simulation. The human 1-16 fragment forms instead a species characterized by $\mathrm{g}_{||}=2.203, \mathrm{~A}_{||}=187 \times 10^{-4} \mathrm{~cm}^{-1}$ [64], which were assigned to a $\mathrm{NH}_{2}, 2 \mathrm{~N}^{-}, \mathrm{N}_{\mathrm{Im}}$ donor set and are nearly identical to the couple of computed values (although a $\mathrm{NH}_{2}, 3 \mathrm{~N}^{-}$chromophore cannot be completely ruled out). All these parameters are nearly equivalent to the obtained computed values, hence confirming the formation of two non-equivalent $(3 \mathrm{~N}$ and $4 \mathrm{~N})$ coordination modes. It can be reasonably inferred that 
at low temperature the $\left[\mathrm{Cu}_{2} \mathrm{LH}_{-4}\right]$ species, which possess $\mathrm{N}_{\mathrm{Im}}, 3 \mathrm{~N}^{-}$and $\mathrm{NH}_{2}, \mathrm{~N}_{\mathrm{Im}}, \mathrm{N}^{-}$ donor sets, may prevail.

In fact, the assignment to the $\left[\mathrm{Cu}_{2} \mathrm{LH}_{-3}\right]$ complex species, which has two nearly equivalent coordination environments, can be discarded. In addition, the $\left[\mathrm{Cu}_{2} \mathrm{LH}_{-5}\right]$ species is characterized by two four-nitrogen coordination environments which should exhibit two $g_{||}$values close to 2.20 and lower, as well as larger $A_{||}$values, as observed at $\mathrm{pH}$ values higher than 8.0. At physiological $\mathrm{pH}$ the deconvolution of the peak at $-0.585 \mathrm{~V}$ gave two peaks centered at $-0.534 \mathrm{~V}$ and $-0.618 \mathrm{~V}$, which confirm the contemporary presence of $\mathrm{N}_{\mathrm{Im}}, 2 \mathrm{~N}^{-}$and $\mathrm{NH}_{2}, 2 \mathrm{~N}^{-}, \mathrm{N}_{\mathrm{Im}}$ donor sets, respectively.

The ESR spectrum run at $\mathrm{pH}=8.5$ shows a broadening of the parallel features due to the presence of similar coordination environments. The averaged Hamiltonian parameters taken from this ESR spectrum are $\mathrm{g}_{||}=2.209, \mathrm{~A}_{||}=194 \times 10^{-4} \mathrm{~cm}^{-1}$ which may be tentatively assigned to the two nearly equivalent copper(II) centers of $\left[\mathrm{Cu}_{2} \mathrm{LH}_{-5}\right]$ species.

Above $\mathrm{pH}=9$ the ESR spectra remain unvaried, with sharp parallel features and Hamiltonian parameters keeping approximately the same values recorded at $\mathrm{pH}=8.5$, i.e., $\mathrm{g}_{||}=2.196, \mathrm{~A}_{||}=205 \times 10^{-4} \mathrm{~cm}^{-1}$, which are assigned to two nearly equivalent coordination environments, $\mathrm{N}_{\mathrm{Im}}, 3 \mathrm{~N}^{-}$and $\mathrm{NH}_{2}, 3 \mathrm{~N}^{-}$, having a four-nitrogen distorted coordination plane. Very similar values were also found for dinuclear $\mathrm{Cu}$ (II) complexes with (1-2,7-21)NPG having such coordination environments [54]. The $\mathrm{E}_{\mathrm{f}}^{\circ}$ value at $-0.571 \mathrm{~V}$ value, increasing the $\mathrm{pH}$ agrees with the presence of four nitrogen atoms in a slight distorted geometry around copper.

The spectra obtained in the 10-11 pH range, as well as their Hamiltonian parameters, are practically unvaried. At these $\mathrm{pH}$ values the deprotonation of lysine and tyrosine residues occurs, but these groups are not involved in the $\mathrm{Cu}(\mathrm{II})$ coordination.

The AcAng1-17 peptide has two histidine residues only as main anchoring points for copper(II) ion, being the amino group acetylated. The acetylation led to a reduction of the dinuclear species. Interestingly, when one $\mathrm{Cu}(\mathrm{II})$ equivalent is added to the peptide solution at $\mathrm{pH} 4$, one or both histidine residues can chelate. In fact, the ESR spectrum showed features (beside those of copper(II) hexaaquo ion) belonging to two complex species. A first set of parameters $\left(\mathrm{g}_{||}=2.332, \mathrm{~A}_{||}=158 \times 10^{-4} \mathrm{~cm}^{-1}\right)$ can be attributed to the initial $\mathrm{Cu}$ (II) anchoring by an histidine imidazole moiety assisted by a carboxylate oxygen donor atom, which is consistent with the $\left[\mathrm{CuLH}_{4}\right]$ species [65]. A SWV peak having a $\mathrm{E}_{\mathrm{f}}^{\circ}$ value of $-0.209 \mathrm{~V}$ was assigned to redox process of this coordination environment. Instead, the second species $\left(\mathrm{g}_{||}=2.295, \mathrm{~A}_{||}=176 \times 10^{-4} \mathrm{~cm}^{-1}\right)$ is due to the $\mathrm{Cu}$ (II) coordination by $2 \mathrm{~N}_{\mathrm{Im}}, \mathrm{O}_{\mathrm{COO}-}, \mathrm{H}_{2} \mathrm{O}$ already observed for $\mathrm{Cu}$ (II)-Ang1-17 at acidic $\mathrm{pH}$, which is the only species recorded by ESR at $\mathrm{pH}=5$, i.e., the $\left[\mathrm{CuLH}_{3}\right]$ species. Such coordination mode is confirmed by the peak $-0.515 \mathrm{~V}$ observed in $\mathrm{SWV}$, analogous to that observed for analogous $\mathrm{Cu}$-Ang1-17 complex.

Two ESR active species were found at $\mathrm{pH}=6$. The first species has $\mathrm{g}_{||}=2.266$, $A_{||}=180 \times 10^{-4} \mathrm{~cm}^{-1}$ and despite the lowering of the $g_{||}$value due to an additional amide donor atom, the hyperfine coupling constant remains almost unvaried. This may be due to a distorted coordination geometry in which the amide nitrogen atom replaces the carboxylate oxygen, i.e., $2 \mathrm{~N}_{\mathrm{Im}}, \mathrm{N}^{-}$equatorial donor set. Such a coordination hypothesis for $\left[\mathrm{CuLH}_{2}\right]$ species is supported by similar spectroscopic data found for $\mathrm{Cu}-\mathrm{Ac}-\mathrm{GHHPHG}-$ $\mathrm{NH}_{2}$ system, and describing the same donor set [66]. The other species, which begins to be present at $\mathrm{pH}=6$, and is the only detectable one until $\mathrm{pH}=8$, is the [CuLH] species. This species presents Hamiltonian parameters which are typical for a four-nitrogen planar coordination environment $\left(\mathrm{g}_{||}=2.212, \mathrm{~A}_{||}=196 \times 10^{-4} \mathrm{~cm}^{-1}\right)$. Its formation is due to the deprotonation of an additional amide nitrogen atom which contributes to the formation of the $\left(2 \mathrm{~N}_{\mathrm{Im}}, 2 \mathrm{~N}^{-}\right)$equatorial donor set. The presence of two complex species at $\mathrm{pH}=6$ is further confirmed by the deconvolution of the broad peak in SWV, resulting in two peaks centered at $-0.594 \mathrm{~V}$ and $-0.662 \mathrm{~V}$, ascribed to redox processes of $\mathrm{Cu}\left(2 \mathrm{~N}_{\mathrm{Im}}, \mathrm{N}^{-}, \mathrm{O}_{\mathrm{COO}-}\right)$, $\mathrm{Cu}\left(2 \mathrm{~N}_{\mathrm{Im}}, 2 \mathrm{~N}^{-}\right)$, respectively. The latter process occurring in the $6.9-8.1 \mathrm{pH}$ range showed practically the same formal potential value. 
On raising the $\mathrm{pH}$ value, the last amide nitrogen is deprotonated and coordinates $\mathrm{Cu}$ (II) by taking the place of an imidazole histidine nitrogen atom, hence forming a $\mathrm{N}_{\mathrm{Im}}$, $3 \mathrm{~N}^{-}$donor set. The coordination of the third amide nitrogen atom causes, as expected, the raising of the hyperfine coupling constant and the lowering of the $\mathrm{g}_{\mid}$।, , (i.e., $\mathrm{g}_{||}=2.199$ and $A_{||}=205 \times 10^{-4} \mathrm{~cm}^{-1}$ ) which have been observed for similar coordination modes. The $\mathrm{E}_{\mathrm{f}}^{\circ}$ value of $-0.580 \mathrm{~V}$ measured in the SWV confirms the presence of a four nitrogen atoms in a distorted arrangement around copper(II).

With the aim of testing the ability to form dicopper(II) species, two equivalents of $\mathrm{Cu}$ (II) were added to a solution of AcAng1-17 peptide. At acidic $\mathrm{pH}$ values (4.3-5.6 $\mathrm{pH}$ range) ESR features belonging to two different species were detected. The simulation of the ESR spectrum gave as a result $\mathrm{g}_{||}=2.332, \mathrm{~A}_{||}=158 \times 10^{-4} \mathrm{~cm}^{-1}$ and $\mathrm{g}_{||}=2.290$, $A_{||}=170 \times 10^{-4} \mathrm{~cm}^{-1}$. The former parameters can be assigned to $\mathrm{N}_{\mathrm{Im}}, \mathrm{O}_{\mathrm{COO}-}$ coordination environment already described for the $\left[\mathrm{CuLH}_{4}\right]$ species [45]. The $\left[\mathrm{CuLH}_{3}\right]$ species is instead described by the latter parameters, which are well suited for $\mathrm{N}_{\mathrm{Im}}, \mathrm{N}^{-}, \mathrm{O}_{\mathrm{COO}-}$ coordination environment [51].

The ESR spectrum run at $\mathrm{pH}$ value of 6.4, apparently disclosing features due to a single species. In fact, a certain degree of broadening indicates that quite similar but different coordination environments are formed. A simulation of the ESR spectrum gave $\mathrm{g}_{||}=2.220, \mathrm{~A}_{||}=184 \times 10^{-4} \mathrm{~cm}^{-1}$ and $\mathrm{g}_{||}=2.200, \mathrm{~A}_{||}=190 \times 10^{-4} \mathrm{~cm}^{-1}$, which can be attributed to the $\left(\mathrm{N}_{\operatorname{Im}}, 2 \mathrm{~N}^{-}\right)$and $\left(\mathrm{N}_{\operatorname{Im}}, 3 \mathrm{~N}^{-}\right)$coordination environments, respectively. Such coordination modes can be attributed to $\left[\mathrm{Cu}_{2} \mathrm{LH}_{-2}\right]$ complex species. This is confirmed by the presence of two cathodic peaks at $-0.565 \mathrm{~V}$ and $-0.631 \mathrm{~V}$ assigned to $\left(\mathrm{N}_{\mathrm{Im}}, 2 \mathrm{~N}^{-}\right)$and $\left(\mathrm{N}_{\mathrm{Im}}, 3 \mathrm{~N}^{-}\right)$coordination mode, respectively.

Starting from about $\mathrm{pH}=7$ both coordination environments have $\left(\mathrm{N}_{\mathrm{Im}}, 3 \mathrm{~N}^{-}\right)$donor sets and the ESR spectra showed few variations in the g-values and their corresponding

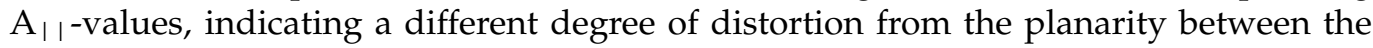
two coordination sites. These deviations from planarity are also reflected by the recorded formal potential, which moves towards a more positive value.

The overall experimental findings indicate that both peptides can bind up to two copper ions in excess of metal concentration. The direct comparison between the stability constant values cannot provide the indication on which peptide binds copper ions more strongly since they form complex species with different deprotonation states.

Being aware of the competition of different ligands in the extracellular space, the ability to bind copper, the coordination environment and geometry can make these angiogeninderived peptides potential players in the variation of copper levels between outside and inside the cell.

The intracellular copper level was studied by means of LSM using a fluorescent probe able to detect the $\mathrm{Cu}(\mathrm{I})$ present inside the cell. Copper at a concentration of $10 \mu \mathrm{M}$ or $20 \mu \mathrm{M}$ increases the amount of copper inside cells, as expected. On the other hand, the addition of free peptide decreases the intracellular copper level, suggesting that both Ang1-17 and Ac Ang1-17 bind copper present in the medium, shifting the balance on both sides of the membrane, so as to induce the cell to release the metal in the extracellular space.

The contemporary addition of an equimolar amount of copper and peptide at $10 \mu \mathrm{M}$ does not reverse the trend to decrease the presence of copper inside cell driven by peptides. By using a 2:1 metal-to-ligand molar ratio, an increase in intracellular copper is observed for peptide Ang1-17, indicating that the peptide can actually act as ionophore or copper shuttle in cases of an excess of copper. This drastic change can be caused by the different copper complex speciation and different coordination environments around the metal when the peptide Ang1-17 binds two copper ions compared to species formed at 1:1 ratio. Remarkably, in the same conditions the peptide AcAng1-17 further decreases the intracellular copper content, maintaining a chelating behavior. Therefore, the environmental conditions can determine a different behavior by the same ligand.

The addition of BCS, a copper chelator, nullified the effect of peptides and copper cells' content was equal to control. 
The effect of the whole protein on intracellular copper levels was also determined. The addition of wtANG induced a strong increase in intracellular copper compared to control. Additionally, for the protein, the addition of BCS inhibits the increase in intracellular ion induced by wtANG, providing indirect evidence that the protein favors the copper cellular uptake.

It can be hypothesized that the protein favors the entry of copper directly or through the activation of other signaling pathways. It is noteworthy that the addition of the recombinant protein, $r A N G$, decreases the copper signal inside cells, as observed for the addition of peptides Ang1-17 and AcAng1-17. It is of note that the only difference between wt-Ang and rANG is the presence of a Met(-1) with a free amino group in the recombinant isoform [44]. The two proteins display the same RNase activity and have the same cellular binding site, showing differences only in presence of copper ions [44]. The decrease in intracellular copper induced by rANG may be ascribed to a direct binding of protein with metal ions, so the rANG may have a metal-chelating activity, as supposed for both Ang1-17 and AcAng1-17 peptides. This is further confirmed by the decrease in copper uptake when the rANG is added together with copper in both 1:1 and 2:1 metal to protein molar ratio; it must be considered that the recombinant protein can bind up two metal ions per molecule [44]. It is important to note that the presence of the thioether group of methionine in rANG could provide an additional donor atom that would also favor copper(I) binding. The obtained data for rANG are similar to those for peptides that do not contain methionine, suggesting the absence of a thioether interaction with the metal ion. Differently, the wtANG can bind only one copper ion and the addition of one or two equivalent show a level of copper comparable to free copper addition at the same concentration. The addition of copper together with wtANG decreases the copper uptake compared to the protein alone.

A hypothesis to rationalize these data is that wtANG can favor cellular uptake through direct binding but in defect of copper and not in presence of equimolar or excess equivalents of metal. At equimolar amounts of copper and wtANG, an equilibrium is achieved whereby the protein no longer carries copper inside. However, these data demonstrate that angiogenin can modulate the cellular uptake of copper. Considering that copper regulates angiogenin expression in endothelial cells, our findings support a strict correlation in protein and metal activity.

It is worth emphasizing the different effect induced by recombinant that limits the uptake of copper present in the culture medium. Frequently, studies on the activity of angiogenin are carried out using the more available recombinant form. This is justified considering that rANG displays the same activities as that wild type ANG normally present in human plasma. Here, we demonstrate that the wild type protein must necessarily be used in the presence of copper to avoid an incorrect conclusion.

The interaction between angiogenin and copper represents a potential target in many pathologies where a dyshomeostasis of copper and an abnormal protein expression are observed, as in tumors.

Peptide fragments belonging to the whole protein able to partially mimic some activities of protein may potentially be used as drugs in these pathologies.

\section{Materials and Methods}

\subsection{Chemicals}

The peptide QDNSRYTHFLTQHYDAK-NH 2 (Ang1-17) and the acetylated analogous peptide Ac-QDNSRYTHFLTQHYDAK-NH2 (AcAng1-17) were supplied by Caslo Aps, Lyngby, Denmark. All other chemicals, of the highest available grade, were purchased from Sigma-Aldrich (Munich, Germany) and used without further purification. For the cellular experiments, Dulbecco's modified eagle medium (DMEM)-F12, penicillin-streptomycin solution, L-glutamine, fetal bovine serum (FBS), Dulbecco's phosphate-buffered saline (PBS) and paraformaldehyde were purchased from Sigma-Aldrich (St. Louis, MO, USA). 


\subsection{Expression and Purification of Angiogenin}

The human ANG expression was carried out according to Holloway et al.'s procedure [67]. Briefly, the E. coli (BL21(DE3)) expression strain was cultured at $37^{\circ} \mathrm{C}$ under shaking $(180 \mathrm{rpm}$ ) in $5 \mathrm{~mL}$ of terrific broth (12 g peptone, $24 \mathrm{~g}$ granulated yeast extract, $4 \mathrm{~mL}$ glycerol $87 \%, 900 \mathrm{~mL}$ of MilliQ water) supplemented with ampicillin $(100 \mu \mathrm{g} / \mathrm{mL})$. The volume of the bacterial culture was inoculated in $1000 \mathrm{~mL}$ of fresh broth, after $24 \mathrm{~h}$. The ANG expression was induced by the addition of $1 \mathrm{mM}$ isopropyl $\beta$-D-1-thiogalactopyranoside (IPTG). Subsequently, the cell culture was harvested by centrifugation (4000 RCF for $15 \mathrm{~min}$ at $4{ }^{\circ} \mathrm{C}$, JLA 8100 ) and cells were lysed by means of lysis buffer ( $50 \mathrm{mM}$ Tris- $\mathrm{HCl}, 2 \mathrm{mM}$ EDTA, $\mathrm{pH}=8$ ), using the high-pressure homogenizer (Emulsiflex) and a sonication step (Qsonica Sonicator Q700, Newtown, CT, USA). Afterwards, the lysate was centrifuged $\left(20,000 \mathrm{RCF}\right.$ for $40 \mathrm{~min}$ at $4{ }^{\circ} \mathrm{C}$, JA25.50) and the pellet was re-suspended in $25 \mathrm{~mL}$ of lysis buffer supplemented with $1 \%(v / v)$ Triton X-100. Sonication and centrifugation steps were repeated twice and the final pellet was dissolved in $30 \mathrm{~mL}$ of denaturation buffer $(0.24 \mathrm{M}$ guanidine hydrochloride $(\mathrm{GdnHCl}), 100 \mathrm{mM}$ Tris- $\mathrm{HCl}, 1 \mathrm{mM}$ ethylenediaminetetraacetic acid (EDTA), $4 \mathrm{mM} \mathrm{NaCl}, 0.4 \mathrm{mM} \mathrm{1,4-dithiothreitol} \mathrm{(DTT)).}$

The recombinant angiogenin obtained ( $\mathrm{r}$-Ang) encompasses a methionine as first residue, Met(-1) and was refolded from inclusion bodies according to the procedure described by Jang et al. [68]. The purification was performed by means of a cation exchange chromatography performed on an automated chromatographic workstation (Akta prime, GE Healthcare, Chicago, Illinois, USA) equipped with a $15 \times 1.6 \mathrm{~cm}$ column packed with SP Sepharose Fast Flow (GE Healthcare, Chicago, Illinois, USA). The protein was eluted with $25 \mathrm{mM}$ Tris- $\mathrm{HCl}, 1 \mathrm{M} \mathrm{NaCl}(\mathrm{pH}=8.0)$ buffer solution.

It is necessary remove the first methionine residue in order to obtain the angiogenin protein with the native sequence, here named wtANG.

The rANG was incubated with $1 \mathrm{nM}$ Aeromonas aminopeptidase, an enzyme that specifically cut the first methionine, at the concentration of $1 \times 10^{-5} \mathrm{M}$ in $200 \mathrm{mM}$ potassium phosphate buffer $(\mathrm{pH}=7.2)$ (overnight at $37^{\circ} \mathrm{C}$ under gentle shaking) [ 10.1016/0003-2697(88)90569-6]. After the remotion of Met(-1), the N-terminal glutamine residue (Glu1) spontaneously cyclizes to the pyroglutamate residue in order to obtain the wtANG. The reaction mixture was purified by dialysis (Spectra/por MWCO 6-8000 Da), which replaces PBS with $25 \mathrm{mM}$ Tris- $\mathrm{HCl}$ ( $\mathrm{pH}$ 7.4) buffer solution, followed by cationexchange chromatography.

\subsection{Electron Spin Resonance Spectroscopy (ESR)}

A Bruker Elexsys E500 CW-EPR spectrometer driven by a PC running the XEpr software and equipped with a Super-X microwave bridge operating at $9.3-9.5 \mathrm{GHz}$ and a SHQE cavity was used throughout this work. All ESR spectra of frozen solution of $\mathrm{Cu}$ (II) complexes were recorded at $150 \mathrm{~K}$ by means of a ER4131VT variable temperature apparatus. In order to increase spectral resolution, a small amount of methanol (not exceeding 10\%) was added to the $\mathrm{Cu}$ (II) complex aqueous solutions, after adjusting the $\mathrm{pH}$ to the desired value, to obtain a good quality glass upon freezing [69]. The ESR magnetic parameters $\mathrm{g}_{\text {। }}$ । and $A_{||}$were extracted from the 2 nd and the 3rd line to remove second order effects [70]. Some experimental spectra were simulated by the program Monoclin [71], which allows researchers to distinguish more species simultaneously present.

\subsection{Potentiometric Titrations}

Potentiometric titrations were performed on a Titrando 905 automatic titrator (Switzerland) using a combined glass- $\mathrm{Ag} / \mathrm{AgCl}$ electrode (Metrohm, Switzerland) The titration cell $(2.5 \mathrm{~mL})$ was thermostated at $298.0 \pm 0.2 \mathrm{~K}$, and all solutions were kept under an atmosphere of argon. $\mathrm{KOH}$ solutions $(0.1 \mathrm{M})$ were added through a Hamilton burette equipped with $1 \mathrm{~cm}^{3}$ syringe. The ionic strength of all solutions was adjusted to $0.10 \mathrm{M}\left(\mathrm{KNO}_{3}\right)$. In order to determine the stability constants, solutions of the ligands with copper(II) ion were titrated using $0.1 \mathrm{M}$ potassium hydroxide. Ligand concentration ranged from 1.0 to 
$1.5 \times 10^{-3} \mathrm{M}$. A minimum of three independent runs were performed to determine the copper(II) complexation constants [72].

Metal-to-ligand ratio of 2:1 was employed. The initial $\mathrm{pH}$ was always adjusted to 2.4. To avoid systematic errors and verify reproducibility, the electromotive force (EMF) values of each experiment were taken at different time intervals.

To obtain complexation constants, the potentiometric data were refined using Hyperquad [73]. The species distribution as a function of the $\mathrm{pH}$ was obtained using the computer program Hyss [74].

\subsection{Ultraviolet-Visible (UV-vis) Measurements}

UV-vis spectra were recorded at $25^{\circ} \mathrm{C}$ using an Agilent 8453 (Agilent Technologies, Santa Clara, CA, USA) or a Jasco V-670 (Jasco, Easton, MD, USA) spectrophotometer. The concentrations of the peptides and copper(II) ion used to record absorption spectra were the same as those for the potentiometric titrations.

Combined spectroscopic and potentiometric metal-complex titrations were performed in a $3 \mathrm{~mL}$ quartz cuvette with a $1 \mathrm{~cm}$ path length to obtain the spectrum in the visible region at each $\mathrm{pH}$ value simultaneously. These experiments were replicated at least three times for each copper-peptide system. Spectroscopic data were processed by means of Hyperquad program [60]. The deconvolution carried out by using Peakfit 4.0.

\subsection{Circular Dichroism (CD) Measurements}

$\mathrm{CD}$ spectra were obtained at $25^{\circ} \mathrm{C}$ under a constant flow of nitrogen on a Jasco model 810 spectropolarimeter (Jasco, Easton, MD, USA) at a scan rate of $50 \mathrm{~nm} \mathrm{~min}{ }^{-1}$ and a resolution of $0.1 \mathrm{~nm}$, the path length being $1 \mathrm{~cm}$, in the $280-800 \mathrm{~nm}$ range. The spectra were recorded as an average of either 3 or 5 scans. Calibration of the instrument was performed with a $0.06 \%$ aqueous solution of ammonium camphorsulfonate. The CD spectra of the copper(II) complexes on varying the solution $\mathrm{pH}$ were obtained in both the 190-250 and 250-800 nm wavelength regions. All the solutions were freshly prepared using double distilled water. The copper(II) ion and peptide concentrations used for the acquisition of the $\mathrm{CD}$ spectra in the visible region were identical to those used in the potentiometric titrations. The results are reported as $\Delta \varepsilon$ (molar dichroic coefficient) in $\mathrm{M}^{-1} \mathrm{~cm}^{-1}$.

\subsection{Voltammetric Study}

Cyclic voltammograms (CV) of the $\mathrm{Cu}$ (II) complexes in solution $\left(5 \times 10^{-4} \mathrm{M}, 0.1 \mathrm{M}\right.$ $\mathrm{KNO}_{3}$ as ground electrolyte) were recorded by means of a Metrohm Autolab PGSTAT 128N potentiostat-galvanostat driven by a standard PC. These solutions were analyzed by using a Metrohm glass cell with a three-electrode assembly: a working glassy carbon electrode ( $2 \mathrm{~mm}$ diameter), a glassy carbon rod as auxiliary electrode and a $\mathrm{Ag} / \mathrm{AgCl}$ reference electrode. All electrodes and parts were manufactured by Metrohm. The cell also hosted a combined 3-mm Metrohm Biotrode micro $\mathrm{pH}$ glass electrode which was connected with a titrator Metrohm Titrando 905 dispensing KOH 0.1 M directly in the cell. The PGSTAT 128N and Titrando 905 are coupled by programming the communications of the driving software (Tiamo 2.4 and Nova 1.11.2) released by Metrohm. Complex solutions were degassed by using ultrapure argon. Electrochemical measurements were generally acquired by sweeping the potential from +0.500 to $-0.900 \mathrm{~V}$. The square wave voltammetry (SWV) experiments were carried out a $15 \mathrm{~Hz}$ frequency with a $25 \mathrm{mV}$ applied pulse value. Cyclic voltammetry (CV) measurements were carried out at $25^{\circ} \mathrm{C}$ with sweep rate of $50 \mathrm{mV} \mathrm{s}^{-1}$ in the same potential range of SWV experiments. All reported potentials are referred to $\mathrm{Ag} / \mathrm{AgCl}$ reference electrode, $+0.212 \mathrm{~V}$ vs. Normal Hydrogen Electrode (NHE), unless otherwise stated. The $\mathrm{Ag} / \mathrm{AgCl}$ electrode potential was checked by using methylviologen redox couple $\left(\mathrm{MV}^{2+} / \mathrm{MV}^{+}\right),-0.446 \mathrm{~V}$ vs. NHE [75]. 


\subsection{Cell Cultures}

Human neuroblastoma (SH-SY5Y) cells were cultured in Dulbecco's modified eagle medium (DMEM)-F12 medium supplemented with 10\% (v/v) FBS, 2 mM L-glutamine, $100 \mathrm{U}$ penicillin $/ 0.1 \mathrm{mg} / \mathrm{mL}$ streptomycin. Cells were grown in tissue-culture treated Corning ${ }^{\circledR}$ flasks (Sigma-Aldrich, St. Louis, MO, USA) under a humidified atmosphere of air $/ \mathrm{CO}_{2}$ (95:5) at $37^{\circ} \mathrm{C}$ in an incubator (Heraeus Hera Cell $150 \mathrm{C}$ incubator).

\subsection{Confocal Microscopy Analysis}

Confocal imaging microscopy was performed with a FV1000 confocal laser scanning microscope (LSM), furnished with diode UV (405 nm, $50 \mathrm{~mW})$, multiline Argon (457 nm, $488 \mathrm{~nm}, 515 \mathrm{~nm}$, total $30 \mathrm{~mW}), \mathrm{HeNe}(\mathrm{G})(543 \mathrm{~nm}, 1 \mathrm{~mW})$ and $\mathrm{HeNe}(\mathrm{R})(633 \mathrm{~nm}, 1 \mathrm{~mW})$ lasers. An oil immersion objective (60xO PLAPO) and spectral filtering systems were used. The detector gain was fixed at a constant value and images were collected, in sequential mode, randomly all through the area of the dish. All images were deconvolved with Huygens Essential software (Scientific Volume Imaging, The Netherlands).

To perform the experiment, SH-SY5Y cells were seeded on glass bottomed dishes (WillCo-dish ${ }^{\circledR}$, Willco Wells, B.V.) with $12 \mathrm{~mm}$ of glass diameter, at a density of $30 \times 10^{3}$ cells per dish, in DMEM-F12 medium with 10\% ( $v / v)$ FBS. After $24 \mathrm{~h}$, medium was changed with DMEM-F12 supplemented with $1 \%(v / v)$ FBS and cells were treated for 90 min with: $0.1 \mu \mathrm{M}, 0.2 \mu \mathrm{M}, 10 \mu \mathrm{M}$ and $20 \mu \mathrm{M} ; 10 \mu \mathrm{M} \mathrm{CuSO}{ }_{4} ; 10 \mu \mathrm{M}$ Ang1-17 and AcAng1-17 in the absence and in the presence of $\mathrm{CuSO}_{4}$ at the concentrations of $10 \mu \mathrm{M}$ and $20 \mu \mathrm{M}$, corresponding to a $\mathrm{Cu}$ /peptide molar ratio of 1 and 2, respectively; $0.1 \mu \mathrm{M}$ wtANG and rANG, in the absence and in the presence of $\mathrm{CuSO}_{4}$ at the concentrations of $0.1 \mu \mathrm{M}$ and $0.2 \mu \mathrm{M}$, corresponding to a $\mathrm{Cu} /$ protein molar ratio of 1 and 2 , respectively.

Following the incubation time, cells were stained with nuclear dye Hoechst33342 $(0.25 \mu \mathrm{g} / \mathrm{mL})$ (Thermo-Fisher Scientific) and $1 \mu \mathrm{M}$ CS1-copper probe and then fixed with high purity $2 \%(w / v)$ paraformaldehyde in PBS.

Supplementary Materials: The following are available online at https:/ / www.mdpi.com/article/10 $.3390 /$ ijms22179530/s1.

Author Contributions: Conceptualization, D.L.M., A.M. (Antonio Magrì) and C.S.; methodology, G.T., S.P., C.S. and D.L.M.; formal analysis, G.T., S.P., T.M., C.S. and D.L.M.; investigation, G.T., L.M.C., A.M. (Alessia Munzone), C.P., A.M. (Antonio Magrì) and D.L.M.; resources, D.L.M., T.M., A.M. (Antonio Magrì) and C.S.; writing-original draft preparation, G.T., A.M. (Antonio Magrì), C.S. and D.L.M.; writing-review and editing, G.T., L.M.C., T.M., S.P., A.M. (Antonio Magrì), C.S. and D.L.M.; funding acquisition, T.M., C.S. and D.L.M. All authors have read and agreed to the published version of the manuscript.

Funding: This work is supported by the University of Pisa under the "PRA—Progetti di Ricerca di Ateneo" Institutional Research Grants_Project no. PRA_2020_58 “Agenti innovativi e nanosistemi per target molecolari nell'ambito dell'oncologia di precisione" and Rating Ateneo 2019-2020. T.M. and D.L. gratefully acknowledge also the Beneficentia Stiftung Foundation, Vaduz (BEN2019/48), This research was also partially funded by the Italian Ministry of University and Research (MUR) (PRIN call, project code: 2017WBZFHL), the ERA-NET Cofund "M-ERA-NET 2" call (Project name "SmartHyCAR", number: 4274), and University of Catania (PIAno di inCEntivi per la RIcerca di Ateneo 2020/2022 CHANCE_Linea di Intervento 1 e GRABIO_Linea di intervento 2).

Acknowledgments: T.M., C.S. and D.L.M. acknowledge the Consorzio Interuniversitario di Ricerca in Chimica dei Metalli nei Sistemi Biologici (C.I.R.C.M.S.B.), Bari, Italy.

Conflicts of Interest: The authors declare no conflict of interest.

\section{References}

1. Lyons, S.M.; Fay, M.M.; Akiyama, Y.; Anderson, P.J.; Ivanov, P. RNA biology of angiogenin: Current state and perspectives. RNA Biol. 2016, 14, 171-178. [CrossRef]

2. Sheng, J.; Xu, Z. Three decades of research on angiogenin: A review and perspective. Acta Biochim. Biophys. Sin. 2016, 48, 399-410. [CrossRef] 
3. Kim, Y.N.; Kim, D.H. Decreased serum angiogenin level in Alzheimer's disease. Prog. Neuro-Psychopharmacol. Biol. Psychiatry 2012, 38, 116-120. [CrossRef]

4. Van Es, M.A.; Schelhaas, H.J.; van Vught, P.W.J.; Ticozzi, N.; Andersen, P.M.; Groen, E.J.N.; Schulte, C.; Blauw, H.M.; Koppers, M.; Diekstra, F.P.; et al. Angiogenin variants in Parkinson disease and amyotrophic lateral sclerosis. Ann. Neurol. $2011,70,964-973$. [CrossRef]

5. Bradshaw, W.J.; Rehman, S.; Pham, T.T.K.; Thiyagarajan, N.; Lee, R.L.; Subramanian, V.; Acharya, K.R. Structural insights into human angiogenin variants implicated in Parkinson's disease and Amyotrophic Lateral Sclerosis. Sci. Rep. 2017, 7. [CrossRef] [PubMed]

6. Prehn, J.H.M.; Jirström, E. Angiogenin and tRNA fragments in Parkinson's disease and neurodegeneration. Acta Pharmacol. Sin. 2020, 41, 442-446. [CrossRef] [PubMed]

7. Tello-Montoliu, A.; Patel, J.V.; Lip, G.Y.H. Angiogenin: A review of the pathophysiology and potential clinical applications. J. Thromb. Haemost. 2006, 4, 1864-1874. [CrossRef]

8. Campos-Melo, D.; Droppelmann, C.A.; Volkening, K.; Strong, M.J. RNA-binding proteins as molecular links between cancer and neurodegeneration. Biogerontology 2014, 15, 587-610. [CrossRef]

9. Greenway, M.J.; Andersen, P.M.; Russ, C.; Ennis, S.; Cashman, S.; Donaghy, C.; Patterson, V.; Swingler, R.; Kieran, D.; Prehn, J.; et al. ANG mutations segregate with familial and 'sporadic' amyotrophic lateral sclerosis. Nat. Genet. 2006, 38, 411-413. [CrossRef] [PubMed]

10. Kishikawa, H.; Wu, D.; Hu, G.-F. Targeting angiogenin in therapy of amyotropic lateral sclerosis. Expert Opin. Ther. Targets 2008, 12, 1229-1242. [CrossRef]

11. Aparicio-Erriu, I.M.; Prehn, J.H.M. Molecular Mechanisms in Amyotrophic Lateral Sclerosis: The Role of Angiogenin, a Secreted RNase. Front. Neurosci. 2012, 6. [CrossRef] [PubMed]

12. Strong, M.J. The evidence for altered RNA metabolism in amyotrophic lateral sclerosis (ALS). J. Neurol. Sci. 2010, 288, 1-12. [CrossRef] [PubMed]

13. Yu, W.; Goncalves, K.A.; Li, S.; Kishikawa, H.; Sun, G.; Yang, H.; Vanli, N.; Wu, Y.; Jiang, Y.; Hu, M.G.; et al. Plexin-B2 Mediates Physiologic and Pathologic Functions of Angiogenin. Cell 2017, 171, 849-864.e825. [CrossRef]

14. Thomas, S.P.; Hoang, T.T.; Ressler, V.T.; Raines, R.T. Human angiogenin is a potent cytotoxin in the absence of ribonuclease inhibitor. RNA 2018, 24, 1018-1027. [CrossRef] [PubMed]

15. Strydom, D.J. The angiogenins. Cell. Mol. Life Sci. (CMLS) 1998, 54, 811-824. [CrossRef]

16. Fett, J.W.; Strydom, D.J.; Lobb, R.R.; Alderman, E.M.; Bethune, J.L.; Riordan, J.F.; Vallee, B.L. Isolation and characterization of angiogenin, an angiogenic protein from human carcinoma cells. Biochemistry 2002, 24, 5480-5486. [CrossRef]

17. Lee, H.-H.; Wang, Y.-N.; Hung, M.-C. Functional roles of the human ribonuclease A superfamily in RNA metabolism and membrane receptor biology. Mol. Asp. Med. 2019, 70, 106-116. [CrossRef]

18. Strydom, D.J.; Fett, J.W.; Lobb, R.R.; Alderman, E.M.; Bethune, J.L.; Riordan, J.F.; Vallee, B.L. Amino acid sequence of human tumor derived angiogenin. Biochemistry 2002, 24, 5486-5494. [CrossRef]

19. Kishimoto, K.; Liu, S.; Tsuji, T.; Olson, K.A.; Hu, G.-f. Endogenous angiogenin in endothelial cells is a general requirement for cell proliferation and angiogenesis. Oncogene 2004, 24, 445-456. [CrossRef]

20. Finney, L.; Mandava, S.; Ursos, L.; Zhang, W.; Rodi, D.; Vogt, S.; Legnini, D.; Maser, J.; Ikpatt, F.; Olopade, O.I.; et al. X-ray fluorescence microscopy reveals large-scale relocalization and extracellular translocation of cellular copper during angiogenesis. Proc. Natl. Acad. Sci. USA 2007, 104, 2247-2252. [CrossRef]

21. Finney, L.; Vogt, S.; Fukai, T.; Glesne, D. Copper and Angiogenesis: Unravelling a Relationship Key to Cancer Progression. Clin. Exp. Pharmacol. Physiol. 2009, 36, 88-94. [CrossRef]

22. La Mendola, D.; Giacomelli, C.; Rizzarelli, E. Intracellular Bioinorganic Chemistry and Cross Talk Among Different -Omics. Curr. Top. Med. Chem. 2016, 16, 3103-3130. [CrossRef] [PubMed]

23. Mathys, Z.K.; White, A.R. Copper and Alzheimer's Disease. Neurotox. Met. 2017, 18, 199-216.

24. Ackerman, C.M.; Chang, C.J. Copper signaling in the brain and beyond. J. Biol. Chem. 2018, 293, 4628-4635. [CrossRef] [PubMed]

25. Urso, E.; Maffia, M. Behind the Link between Copper and Angiogenesis: Established Mechanisms and an Overview on the Role of Vascular Copper Transport Systems. J. Vasc. Res. 2015, 52, 172-196. [CrossRef] [PubMed]

26. Petcu, E.-B.; Andrei, A.; Popa-Wagner, A.; Uzoni, A.; Gaman, A.M. The Role of Oxidative Stress in Etiopathogenesis of Chemotherapy Induced Cognitive Impairment (CICI)-“Chemobrain”. Aging Dis. 2016, 7. [CrossRef]

27. Jiang, D.; Men, L.; Wang, J.; Zhang, Y.; Chickenyen, S.; Wang, Y.; Zhou, F. Redox Reactions of Copper Complexes Formed with Different $\beta$-Amyloid Peptides and Their Neuropathalogical Relevance. Biochemistry 2007, 46, 9270-9282. [CrossRef] [PubMed]

28. Barnham, K.J.; Bush, A.I. Metals in Alzheimer's and Parkinson's Diseases. Curr. Opin. Chem. Biol. 2008, 12, 222-228. [CrossRef]

29. Girvan, P.; Teng, X.; Brooks, N.J.; Baldwin, G.S.; Ying, L. Redox Kinetics of the Amyloid- $\beta$-Cu Complex and Its Biological Implications. Biochemistry 2018, 57, 6228-6233. [CrossRef]

30. Bacchella, C.; Dell'Acqua, S.; Nicolis, S.; Monzani, E.; Casella, L. Oxidase Reactivity of CuII Bound to N-Truncated A $\beta$ Peptides Promoted by Dopamine. Int. J. Mol. Sci. 2021, 22, 5190. [CrossRef]

31. Cheignon, C.; Jones, M.; Atrián-Blasco, E.; Kieffer, I.; Faller, P.; Collin, F.; Hureau, C. Identification of key structural features of the elusive $\mathrm{Cu}-\mathrm{A} \beta$ complex that generates ROS in Alzheimer's disease. Chem. Sci. 2017, 8, 5107-5118. [CrossRef] [PubMed] 
32. Esmieu, C.; Guettas, D.; Conte-Daban, A.; Sabater, L.; Faller, P.; Hureau, C. Copper-Targeting Approaches in Alzheimer's Disease: How To Improve the Fallouts Obtained from in Vitro Studies. Inorg. Chem. 2019, 58, 13509-13527. [CrossRef] [PubMed]

33. Manoharan, S.; Guillemin, G.J.; Abiramasundari, R.S.; Essa, M.M.; Akbar, M.; Akbar, M.D. The Role of Reactive Oxygen Species in the Pathogenesis of Alzheimer's Disease, Parkinson's Disease, and Huntington's Disease: A Mini Review. Oxidative Med. Cell. Longev. 2016, 2016, 8590578. [CrossRef] [PubMed]

34. Hemerková, P.; Vališ, M. Role of Oxidative Stress in the Pathogenesis of Amyotrophic Lateral Sclerosis: Antioxidant Metalloenzymes and Therapeutic Strategies. Biomolecules 2021, 11, 437. [CrossRef]

35. Zheng, J.; Goch, W.; Bal, W. Numerical Simulations Reveal Randomness of Cu(II) Induced A $\beta$ Peptide Dimerization under Conditions Present in Glutamatergic Synapses. PLoS ONE 2017, 12, e0170749. [CrossRef]

36. Kardos, J.; Héja, L.; Simon, Á.; Jablonkai, I.; Kovács, R.; Jemnitz, K. Copper signalling: Causes and consequences. Cell Commun. Signal. 2018, 16. [CrossRef]

37. Shanbhag, V.C.; Gudekar, N.; Jasmer, K.; Papageorgiou, C.; Singh, K.; Petris, M.J. Copper metabolism as a unique vulnerability in cancer. Biochim. Biophys. Acta (BBA)-Mol. Cell Res. 2021, 1868. [CrossRef]

38. Hoang, T.T.; Johnson, D.A.; Raines, R.T.; Johnson, J.A. Angiogenin activates the astrocytic Nrf2/antioxidant-response element pathway and thereby protects murine neurons from oxidative stress. J. Biol. Chem. 2019, 294, 15095-15103. [CrossRef]

39. Giacomelli, C.; Trincavelli, M.L.; Satriano, C.; Hansson, Ö.; La Mendola, D.; Rizzarelli, E.; Martini, C. Copper (II) ions modulate Angiogenin activity in human endothelial cells. Int. J. Biochem. Cell Biol. 2015, 60, 185-196. [CrossRef]

40. Badet, J.; Soncin, F.; Guitton, J.D.; Lamare, O.; Cartwright, T.; Barritault, D. Specific binding of angiogenin to calf pulmonary artery endothelial cells. Proc. Natl. Acad. Sci. USA 1989, 86, 8427-8431. [CrossRef]

41. Soncin, F.; Guitton, J.-D.; Cartwright, T.; Badet, J. Interaction of Human Angiogenin with Copper Modulates Angiogenin Binding to Endothelial Cells. Biochem. Biophys. Res. Commun. 1997, 236, 604-610. [CrossRef]

42. Naletova, I.; Cucci, L.M.; D'Angeli, F.; Anfuso, C.D.; Magrì, A.; La Mendola, D.; Lupo, G.; Satriano, C. A Tunable Nanoplatform of Nanogold Functionalised with Angiogenin Peptides for Anti-Angiogenic Therapy of Brain Tumours. Cancers 2019, 11, 1322. [CrossRef]

43. Cucci, L.M.; Trapani, G.; Hansson, Ö.; La Mendola, D.; Satriano, C. Gold Nanoparticles Functionalized with Angiogenin for Wound Care Application. Nanomaterials 2021, 11, 201. [CrossRef] [PubMed]

44. La Mendola, D.; Arnesano, F.; Hansson, Ö.; Giacomelli, C.; Calò, V.; Mangini, V.; Magrì, A.; Bellia, F.; Trincavelli, M.L.; Martini, C.; et al. Copper binding to naturally occurring, lactam form of angiogenin differs from that to recombinant protein, affecting their activity. Metallomics 2016, 8, 118-124. [CrossRef] [PubMed]

45. Magrì, A.; Munzone, A.; Peana, M.; Medici, S.; Zoroddu, M.; Hansson, O.; Satriano, C.; Rizzarelli, E.; La Mendola, D. Coordination Environment of $\mathrm{Cu}(\mathrm{II})$ Ions Bound to N-Terminal Peptide Fragments of Angiogenin Protein. Int. J. Mol. Sci. 2016, 17, 1240. [CrossRef] [PubMed]

46. Miller, E.W.; Zeng, L.; Domaille, D.W.; Chang, C.J. Preparation and use of Coppersensor-1, a synthetic fluorophore for live-cell copper imaging. Nat. Protoc. 2006, 1, 824-827. [CrossRef]

47. Kowalik-Jankowska, T.; Ruta-Dolejsz, M.; Wiśniewska, K.; Łankiewicz, L. Coordination of copper(II) ions by the 11-20 and 11-28 fragments of human and mouse $\beta$-amyloid peptide. J. Inorg. Biochem. 2002, 92, 1-10. [CrossRef]

48. Magrì, A.; Pietropaolo, A.; Tabbì, G.; La Mendola, D.; Rizzarelli, E. From Peptide Fragments to Whole Protein: Copper(II) Load and Coordination Features of IAPP. Chem.-A Eur. J. 2017, 23, 17898-17902. [CrossRef]

49. Rajković, S.; Kállay, C.; Serényi, R.; Malandrinos, G.; Hadjiliadis, N.; Sanna, D.; Sóvágó, I. Complex formation processes of terminally protected peptides containing two or three histidyl residues. Characterization of the mixed metal complexes of peptides. Dalton Trans. 2008. [CrossRef]

50. La Mendola, D.; Magrì, A.; Campagna, T.; Campitiello, M.A.; Raiola, L.; Isernia, C.; Hansson, Ö.; Bonomo, R.P.; Rizzarelli, E. A Doppel $\alpha$-Helix Peptide Fragment Mimics the Copper(II) Interactions with the Whole Protein. Chem.-A Eur. J. 2010, 16, 6212-6223. [CrossRef]

51. La Mendola, D.; Magrì, A.; Vagliasindi, L.I.; Hansson, Ö.; Bonomo, R.P.; Rizzarelli, E. Copper(ii) complex formation with a linear peptide encompassing the putative cell binding site of angiogenin. Dalton Trans. 2010, 39. [CrossRef]

52. Sóvágó, I.; Ősz, K. Metal ion selectivity of oligopeptides. Dalton Trans. 2006, 3841-3854. [CrossRef]

53. Łuczkowski, M.; Kozlowski, H.; Stawikowski, M.; Rolka, K.; Gaggelli, E.; Valensin, D.; Valensin, G. Is the monomeric prion octapeptide repeat PHGGGWGQ a specific ligand for $\mathrm{Cu}^{2+}$ ions? J. Chem. Soc. Dalton Trans. 2002, 2269-2274. [CrossRef]

54. Jankowska, E.; Pietruszka, M.; Kowalik-Jankowska, T. Coordination of copper(ii) ions by the fragments of neuropeptide gamma containing D1, H9, H12residues and products of copper-catalyzed oxidation. Dalton Trans. 2012, 41, 1683-1694. [CrossRef] [PubMed]

55. Tabbì, G.; Giuffrida, A.; Bonomo, R.P. Determination of formal redox potentials in aqueous solution of copper(II) complexes with ligands having nitrogen and oxygen donor atoms and comparison with their EPR and UV-Vis spectral features. J. Inorg. Biochem. 2013, 128, 137-145. [CrossRef] [PubMed]

56. White, A.R.; Barnham, K.J.; Huang, X.; Voltakis, I.; Beyreuther, K.; Masters, C.L.; Cherny, R.A.; Bush, A.I.; Cappai, R. Iron inhibits neurotoxicity induced by trace copper and biological reductants. JBIC J. Biol. Inorg. Chem. 2004, 9, 269-280. [CrossRef] [PubMed]

57. Gordge, M.P.; Meyer, D.J.; Hothersall, J.; Neild, G.H.; Payne, N.N.; Noronha-Dutra, A. Copper chelation-induced reduction of the biological activity of S-nitrosothiols. Br. J. Pharmacol. 1995, 114, 1083-1089. [CrossRef] [PubMed] 
58. Pandini, G.; Satriano, C.; Pietropaolo, A.; Gianì, F.; Travaglia, A.; La Mendola, D.; Nicoletti, V.G.; Rizzarelli, E. The Inorganic Side of NGF: Copper(II) and Zinc(II) Affect the NGF Mimicking Signaling of the N-Terminus Peptides Encompassing the Recognition Domain of TrkA Receptor. Front. Neurosci. 2016, 10. [CrossRef]

59. Lutsenko, S. Copper trafficking to the secretory pathway. Metallomics 2016, 8, 840-852. [CrossRef]

60. Öhrvik, H.; Thiele, D.J. How copper traverses cellular membranes through the mammalian copper transporter 1, Ctr1. Ann. N. Y. Acad. Sci. 2014, 1314, 32-41. [CrossRef] [PubMed]

61. Kowalik-Jankowska, T.; Ruta, M.; Wiśniewska, K.; Łankiewicz, L. Coordination abilities of the 1-16 and 1-28 fragments of $\beta$-amyloid peptide towards copper(II) ions: A combined potentiometric and spectroscopic study. J. Inorg. Biochem. 2003, 95, 270-282. [CrossRef]

62. La Mendola, D.; Farkas, D.; Bellia, F.; Magrì, A.; Travaglia, A.; Hansson, Ö.; Rizzarelli, E. Probing the Copper(II) Binding Features of Angiogenin. Similarities and Differences between a N-Terminus Peptide Fragment and the Recombinant Human Protein. Inorg. Chem. 2012, 51, 128-141. [CrossRef]

63. Sanna, D.; Micera, G.; Kállay, C.; Rigó, V.; Sóvágó, I. Copper(ii) complexes of N-terminal protected tri- and tetra-peptides containing histidine residues. Dalton Trans. 2004, 2702-2707. [CrossRef] [PubMed]

64. Kowalik-Jankowska, T.; Rajewska, A.; Wiśniewska, K.; Grzonka, Z.; Jezierska, J. Coordination abilities of N-terminal fragments of $\alpha$-synuclein towards copper(II) ions: A combined potentiometric and spectroscopic study. J. Inorg. Biochem. 2005, 99, $2282-2291$. [CrossRef]

65. Kállay, C.; Nagy, Z.; Várnagy, K.; Malandrinos, G.; Hadjiliadis, N.; Sóvágó, I. Thermodynamic and Structural Characterization of the Copper(II) Complexes of Peptides Containing Both Histidyl and Aspartyl Residues. Bioinorg. Chem. Appl. 2007, 2007, 30394. [CrossRef] [PubMed]

66. Magrì, A.; Grasso, G.; Corti, F.; Finetti, F.; Greco, V.; Santoro, A.M.; Sciuto, S.; La Mendola, D.; Morbidelli, L.; Rizzarelli, E. Peptides derived from the histidine-proline rich glycoprotein bind copper ions and exhibit anti-angiogenic properties. Dalton Trans. 2018, 47, 9492-9503. [CrossRef]

67. Holloway, D.E.; Hares, M.C.; Shapiro, R.; Subramanian, V.; Acharya, K.R. High-Level Expression of Three Members of the Murine Angiogenin Family in Escherichia coli and Purification of the Recombinant Proteins. Protein Expr. Purif. 2001, $22,307-317$. [CrossRef] [PubMed]

68. Jang, S.-H.; Kang, D.-K.; Chang, S.-I.; Scheraga, H.A.; Shin, H.-C. High level production of bovine angiogenin in E. coli by an efficient refolding procedure. Biotechnol. Lett. 2004, 26, 1501-1504. [CrossRef]

69. La Mendola, D.; Magrì, A.; Hansson, Ö.; Bonomo, R.P.; Rizzarelli, E. Copper(II) complexes with peptide fragments encompassing the sequence 122-130 of human doppel protein. J. Inorg. Biochem. 2009, 103, 758-765. [CrossRef]

70. Lund, A.; Callens, F.; Sagstuen, E. Determination of the g-, hyperfine coupling- and zero-field splitting tensors in EPR and ENDOR using extended Matlab codes. J. Magn. Reson. 2021, 325. [CrossRef]

71. Pilbrow, J.R.; Winfield, M.E. Computer simulation of low symmetry E.S.R. spectra due to vitamin B12rand model systems. Mol. Phys. 1973, 25, 1073-1092. [CrossRef]

72. Bellia, F.; La Mendola, D.; Maccarrone, G.; Mineo, P.; Vitalini, D.; Scamporrino, E.; Sortino, S.; Vecchio, G.; Rizzarelli, E. Copper(II) complexes with $\beta$-cyclodextrin-homocarnosine conjugates and their antioxidant activity. Inorg. Chim. Acta 2007, 360, 945-954. [CrossRef]

73. Gans, P.; Sabatini, A.; Vacca, A. Investigation of equilibria in solution. Determination of equilibrium constants with the HYPERQUAD suite of programs. Talanta 1996, 43, 1739-1753. [CrossRef]

74. Alderighi, L.; Gans, P.; Ienco, A.; Peters, D.; Sabatini, A.; Vacca, A. Hyperquad simulation and speciation (HySS): A utility program for the investigation of equilibria involving soluble and partially soluble species. Coord. Chem. Rev. 1999, 184, 311-318. [CrossRef]

75. Kaifer, A.E.; Bard, A.J. Micellar effects on the reductive electrochemistry of methylviologen. J. Phys. Chem. 2002, 89, 4876-4880. [CrossRef] 